This is the peer reviewed version of the following article: Gurnell, A.M. 2014. Plants as river system engineers. Earth Surface Processes and Landforms 39, 4-25, which has been published in final form at DOI: 10.1002/esp.3397. This article may be used for noncommercial purposes in accordance with Wiley Terms and Conditions for Self-Archiving

\title{
Plants as river system engineers
}

Angela Gurnell

School of Geography, Queen Mary, University of London, London E1 4NS

\begin{abstract}
Plants growing within river corridors both affect and respond to fluvial processes. Their above ground biomass modifies the flow field and retains sediment, whereas their below-ground biomass affects the hydraulic and mechanical properties of the substrate and consequently the moisture regime and erosion susceptibility of the land surface.
\end{abstract}

This paper reviews research that dates back to the 1950s on the geomorphological influence of vegetation within fluvial systems. During the late twentieth century this research was largely pursued through field observations, but during the early years of the twenty-first century, complementary field, flume and theoretical/modelling investigations have contributed to major advances in understanding the influence of plants on fluvial systems. Flume experiments have demonstrated the fundamental role of vegetation in determining river planform, particularly transitions from multi- to single-thread forms, and have provided insights into flowvegetation-sediment feedbacks and landform building, including processes such as channel blockage and avulsion. At the same time, modellers have incorporated factors such as moisture-dependent plant growth, canopy and root architecture and their influence on flow resistance and sediment/bank reinforcement into morphodynamic models. Meanwhile, field investigations have revealed that vegetation has a far more important and complex influence on fluvial systems than previously realised.

It is now apparent that the influence of plants on river systems is significant across space scales from individual plants to entire forested river corridors. Small plant-scale phenomena structure patch-scale geomorphological forms and processes, and interactions between patches are almost certainly crucial to larger-scale and longer-term geomorphological phenomena. The influence of plants also varies continuously through time as above and below ground biomass change within the annual growth cycle, over longer-term growth trajectories, and in response to external drivers of change such as climatic, hydrological and fluvial fluctuations and extremes.

\section{KEYWORDS}


Riparian, aquatic macrophyte, ecosystem engineer, pioneer landform, river planform

\section{Introduction}

The fundamental controls on fluvial morphodynamics have long been recognized as the frequency and magnitude of river discharge, and the related erosion, transport and deposition of sediment, moderated by sediment supply and valley gradient. These processes have been the focus of research seeking to explain river form and dynamics for well over half a century. Research contributions by Lane (1957) and Leopold and Wolman (1957) are often cited as marking the beginning of an era in which geomorphologists have concentrated on explaining river form through an increasingly sophisticated understanding of the controlling fluvial processes. Recognition of vegetation as a control on river corridor form and dynamics, rather than just a response to the constraints imposed by fluvial processes and forms, commenced at a similar time. Notably, Mackin (1956) observed that the Wood River, Idaho, alternated between meandering and braided planforms as its marginal vegetation changed from forest to prairie. During the second half of the twentieth century, research on the geomorphological influence of vegetation within fluvial systems was largely pursued through field observations. Building on this research during the early years of the twenty-first century, complementary field, flume and theoretical investigations have contributed to major advances in understanding the influence of plants on fluvial systems.

This review explores the development of research on vegetation and fluvial geomorphology, emphasizing investigations that stress the importance of living vegetation as a physical influence on fluvial systems. The review concentrates on the humid temperate zone, since this is the environmental context in which most of the research has been undertaken, but reference is made to other environmental contexts where pertinent, particularly introducing the significant body of research conducted in arid environments. There is an enormous literature on large (dead) wood and fluvial geomorphology (see Gurnell, 2013 for a recent review) and so the geomorphological role of wood will only be reviewed where it interacts with living vegetation or, through sprouting, underpins vegetation regeneration.

Plants within river corridors both affect and respond to fluvial processes. Their above ground biomass modifies the flow field (e.g., Bennett et al., 2008; Liu et al., 2010) and retains sediment (e.g. Corenblit et al., 2009; Zong and Nepf, 2010), whereas their below-ground biomass affects the hydraulic and mechanical properties of the substrate (e.g. Docker and Hubble, 2008, Pollen-Bankhead and Simon, 2010; Burylo et al., 2012), and consequently the moisture regime and erosion susceptibility of the land surface. This review particularly highlights the role of plant groups and species that act as physical engineers of river ecosystems (sensu Jones et al., 1994), not only responding to their physical environment but 
also modifying it and thus controlling aquatic and riparian ecosystem structure and function as well as river morphodynamics.

Following an overview of geomorphological research since the 1950s that has explored vegetation as a control on alluvial river behaviour, three themes are developed, coupling reference to the broader literature with examples and illustrations from the author's research:

(i) Physical environmental controls on vegetation within river corridors,

(ii) Traits of plant species and groups that are capable of influencing the geomorphology of fluvial environments,

(iii) The processes by which plants influence river form and dynamics.

\section{Vegetation as a control on alluvial river behaviour}

The aim of this section is to provide a broad overview of geomorphological research conducted since the mid-20 $20^{\text {th }}$ century that is relevant to understanding the contribution of vegetation to the form and dynamics of fluvial systems. Although researchers have recognized the potential influence of vegetation on fluvial systems since the middle of the $20^{\text {th }}$ century, this topic has attracted rapidly increasing attention since the beginning of the $21^{\text {st }}$ century. Many aspects of the enormous literature on this theme have been reviewed recently by researchers drawn from the disciplines of geomorphology and ecology (e.g. Bornette et al., 2008; Corenblit and Steiger, 2009; Corenblit et al., 2007, 2008, 2009, 2010; 2011; Folkard, 2009; Francis et al., 2009; Gurnell et al., 2005, 2012; Murray et al., 2008; Osterkamp and Hupp, 2010, 2012; Steiger et al., 2005; Stoffel and Wilford, 2012; Tabacchi et al., 2009; Viles et al., 2008).

Early observations

During the latter part of the $20^{\text {th }}$ century, with a few notable exceptions, fluvial geomorphological research incorporating vegetation was based on field observations and supported investigation of three main themes: associations between vegetation and channel width; associations between vegetation and specific fluvial landforms; and how vegetation directly influences fluvial forms and processes.

From an early stage, field observations indicated an association between the channel width of relatively small streams and their bank vegetation (e.g. Zimmerman et al., 1967; Murgatroyd and Ternan, 1983; Davies-Colley, 1997; Trimble, 1997; Huang and Nanson, 1997; Hession et al., 2003; Sweeney et al., 2004). Although the types and densities of vegetation varied, in 
most cases forest-lined river channels were found to be wider than those bordered by nonwoody vegetation.

Many field investigations also identified associations between spatial patterns in vegetation structure and composition, and river channel and floodplain landforms and their evolution (e.g Hupp, 1983, 1986; Osterkamp and Hupp, 1984; Pautou and Décamps, 1985; Bren and Gibbs, 1986; Menges, 1986; Salo et al., 1986; Harris, 1987; Bren, 1988; Hughes, 1988; Rowntree, 1991; Puhakka et al., 1992; Décamps and Tabacchi, 1994; Birkeland, 1996; Hupp and Osterkamp, 1996; van Coller et al., 1997, 2000; Hughes et al., 1997; Huggenberger et al., 1998; Osterkamp, 1998; Kollmann et al., 1999; Robertson and Augspurger, 1999). This led to research emphasising the consequences of changes in fluvial processes, including flow regulation, for channel size and morphology, and riparian vegetation spatial extent, succession and structure (e.g. Pautou et al., 1985; Johnson, 1994, 1997; Scott et al., 1996; Robach et al.,1997; Friedman and Auble, 1999; Marston et al.,1995; Rood and Mahoney, 1995; Scott et al., 1996; Stromberg and Patten, 1996; Dominick and O'Neill, 1998; Swanson et al., 1998; Friedman and Auble, 1999; Bendix and Hupp, 2000, Merritt and Cooper, 2000). In general, these studies identified the importance of the river flow regime (average flows and frequency-duration of extreme flows) and alluvial groundwater regime for both supporting and disrupting riparian plant dispersal, growth and establishment. In some cases, researchers also identified how changes in fluvial processes induced adjustments in channel morphology and substrate characteristics, which further impacted riparian vegetation character and spatial extent.

Some research also explored the impact of vegetation on fluvial processes and dynamics, including studies of bank processes; channel dynamics; channel planform styles; and the development of particular landforms. In relation to bank erosion / aggradation, important early experiments with silty bank materials by Smith (1976) estimated a 20,000 time increase in erosion resistance when these materials included up to an $18 \%$ volume root mat. At a larger spatial scale, Simon and Hupp (1990) noted the importance of vegetation development on lateral bars and benches for accelerating sediment retention and cross profile recovery of enlarged and straightened channels; Friedman et al. (1996) stressed the importance of sediment trapping by colonizing vegetation in inducing channel narrowing following major erosive flood events along Plum Creek, Colorado; Kondolf and Curry $(1984,1986)$ and Madej et al. (1994) described decreased bank stability and channel widening (including transitions from meandering to braiding planforms) as a resulted of a decrease in riparian vegetation biomass along the Carmel and Merced Rivers, California, USA; and Graf $(1978,1982)$ and Rowntree (1991) identified channel narrowing associated with increased sediment trapping and reinforcement by alien riparian woody plant species invading river corridors in SW USA and S Africa, respectively. Riparian vegetation was also noted as an influence on the erosion resistance and stability of levées (e.g. Shields and Gray, 1992; Dwyer et al., 1997). Overall, 
the importance of vegetation for bank stability and erosion resistance is conditioned by the size, structure and biomechanical properties of both the above- and below-ground biomass (Greenaway, 1987; Coppin and Richards, 1990; Thorne, 1990; Gray and Sotir, 1996). The role of vegetation was also hypothesised to vary along river systems as plants interact with other physical processes that affect bank erosion, such as subaerial preparation, fluvial entrainment, and mass failure (Abernethy and Rutherfurd, 1998).

Interest in the impact of vegetation on river banks was also directed at channel migration rates and processes. In the context of meandering rivers, Nanson and Beach (1977) identified a clear association between riparian forest age structure and species composition, and sedimentation and lateral migration of the Beatton River, British Columbia; whereas Beeson and Doyle (1995), also working in British Columbia, found that major bank erosion during large floods was 30 times more prevalent on non-vegetated bends than on vegetated bends, and Burckhardt and Todd (1998), working in Missouri, found that bends with unforested concave banks had an average migration rate three times greater than those with forested concave banks. On small sinuous rivers, vegetation can induce particular styles of bank erosion (e.g. Davis and Gregory, 1994), whereas on larger rivers, vegetation-associated point and counterpoint bar and bench development and scroll formation have been noted as specific biogeomorphological features of meander migration by Nanson (1981), Page and Nanson (1982) and McKenney et al. (1995), whereas Kochel et al. (1987) attributed pseudoterrace construction to tree jams in the Little River valley, Virginia.

Several researchers also identified vegetation as a key control on channel planform, in particular in relation to transitions between multithread and single thread planforms (Kondolf and Curry, 1984, 1986); maintaining island ridges in ephemeral anabranching rivers (Wende and Nanson, 1998; Tooth and Nanson, 1999); controlling channel change in perennial anastomosing systems (e.g. Harwood and Brown, 1993); and influencing the morphology and stability of floodplains (Featherston et al., 1995; Piégay, 1997).

In addition to results drawn from individual field research investigations, several review papers synthesized field research results to advance understanding of the role of vegetation within fluvial systems. Hickin (1984), Gregory and Gurnell (1988) and Thornes (1990) identified a range of mechanisms through which vegetation affected fluvial forms and processes, and Gregory et al. (1991), Naiman and Décamps (1997) and Gurnell (1997) emphasized riparian processes and dynamics across different space and time scales. A particularly ground-breaking research synthesis by Nanson and Knighton (1996) explored different styles of anabranching river. Although the authors did not explicitly identify vegetation as a control on river morphodynamics, some aspect of dead or living vegetation was mentioned in association with virtually all of the anabranching river types that they described. Reference was made to the role of aquatic vegetation in retaining sediment and 
inducing avulsions in low energy organic systems; to stabilization of channel and island banks by riparian vegetation in low energy organo-clastic and sand dominated systems and in higher energy gravel-dominated systems; to damming of higher energy gravel-dominated systems by large wood, and to the creation and maintainance of ridge-shaped islands as a result of within-channel tree growth in higher energy sand-dominated systems.

Recent advances: Flume Experiments

The early years of the twenty-first century have seen enormous advances in understanding the importance of vegetation as a physical component of fluvial systems. This has been achieved through a combination of experimental research in flumes and advances in physically-based modeling, as well as through numerous field investigations.

Flume experiments have explored interactions between flow, sediment and submerged, emergent and riparian plants in an increasingly realistic way. These experiments have detailed vegetation impacts on three dimensional flow structures under different discharge and vegetation (stem density, canopy architecture, flexibility, patch configuration etc.) conditions, whose geomorphological significance can be interpreted in relation to the potential for retention, erosion and redistribution of river bed and bank sediment (e.g. Lopez and Garcia, 1998; Sharpe and James, 2006; Hopkinson and Wynn, 2009; Liu et al., 2010; McBride et al., 2007; Zong and Nepf, 2010; Bal et al., 2011; Chen et al., 2011). Of particular biogeomorphological interest is the experiment conducted by McBride et al. (2007), which compared non-forested (synthetic grass carpet) with forested (rigid wooden dowels) riparian vegetation and found a narrow band of high turbulence between the floodplain and main channel for forested runs (turbulent kinetic energy twice that of non-forested runs), which may induce enhanced sediment entrainment and transport and thus higher channel widths in forest-lined channels.

Flume experiments have also investigated the impact of vegetation on river channel morphodynamics and planform. These experiments have shown that marginal patches of emergent vegetation in overwidened, straight channels can induce channel narrowing and increased sinuosity (Bennett, 2004; Bennett et al., 2002, 2008) and that vegetation is a key ingredient in the simplification of river planform and the maintenance of single thread channels (e.g. Gran and Paola, 2001; Tal et al., 2004; Jang and Shimizu, 2007; Tal and Paola, 2007; Braudrick et al., 2009; Li and Millar, 2010), by reinforcing sediment and so reducing channel widening and channel cutoffs (Tal and Paola, 2010). Recently the impact of vegetation growth stage and rate have been explored (Crouzy and Perona, 2012; Perona et al., 2012), showing that as vegetation establishes under the same flow and sediment supply conditions, sediment retention increases; fewer, less mobile, narrower and deeper channels 
are maintained; and plants with small rooting depth are preferentially eroded, leaving deeper rooted plants stabilizing sediment. These observations complement research over geological time scales (Davies and Gibling, 2009, 2010; Gibling and Davies, 2012) that indicates a change from predominantly braided to meandering river planforms across the Earth's surface as rooted vegetation capable of stabilising river banks evolved, but also the development of some more complex anabranching systems with the appearance of woody vegetation and log jams that induced avulsions. Whilst many flume experiments indicate a simplification of planform in response to bank and floodplain vegetation in perennially-flowing systems, Coulthard (2005) showed that vegetation growth in ephemeral rivers may cause the flow to divide, increasing the number of channels in a manner similar to that observed in the field (e.g. Tooth and Nanson, 2000). Indeed, all of these results are consistent with earlier field studies (see previous section), and clearly confirm that plants are not a passive component of rivers, they are crucial to large scale river morphodynamics.

In summary and from a geomorphological perspective, recent research using flumes has highlighted the fundamental role of vegetation in determining river planform, particularly influencing transitions from multi- to single-thread planforms. It has also provided insights into vegetation-related processes leading to channel blockage and avulsion (e.g. Tal and Paola, 2010); into flow-vegetation-sediment feedbacks and landform building (e.g. Braudrick et al., 2009; Li and Millar, 2011); and images from some experiments illustrate the formation of pioneer vegetated landforms as vegetation colonises bare sediment features (e.g. Figure 6 in Tal and Paola, 2010,), a topic that is discussed in detail below.

Recent advances: Modelling

While flume experiments have revealed the role of plants as physical engineers of river channels, modelling research has allowed the processes underpinning this role to be investigated in detail. One major focus, highly relevant to river channel dynamics, has been modelling of the impact of riparian vegetation on bank stability and erosion resistance. In this context, there have been major advances in characterizing the way in which plant root systems reinforce river banks (e.g. Pollen and Simon, 2005, Pollen-Bankhead and Simon, 2009; Nygren et al., 2009) and the impact of plant biomass on bank surcharge and failure (e.g. van de Wiel and Darby 2007). Using such models, it has been possible to compare the effects of different riparian plant species on bank stability / erodibility, including alien invasive riparian species (e.g. Pollen-Bankhead et al., 2009), and emergent aquatic species (e.g. Pollen-Bankhead et al., 2011). In combination with field and laboratory observations, the relative importance of vegetation-related hydrological and hydraulic processes for bank stability have also been investigated (e.g. Simon and Collison, 2002; Pollen-Bankhead and Simon, 2010), including seepage undercutting (Cancienne et al., 2008). 
A second area of modeling advance has examined the aggregate impact of riparian vegetation on river planform. By representing the overall effect of vegetation on bank stability in terms of a friction angle, Millar (2000) defined a theoretical criterion for the meanderbraiding transition that incorporated bank full discharge, $D_{50}$ and bank vegetation and showed good discrimination when compared with field data. Subsequently, Millar (2005) introduced relative bank strength (the ratio of the critical shear stresses for the bank and bed sediments) to incorporate bank vegetation into theoretical regime equations for gravel bed rivers. Relative bank strength has been used, along with dimensionless discharge and slope, to define thresholds between rivers with single thread, transitional and braided planforms (Eaton et al., 2010) and to explore impacts of vegetation on downstream hydraulic geometry and migration in channels of different size (Eaton and Giles, 2009).

Lastly, modeling has also explored the dynamic impact of vegetation on river channel adjustments. Murray and Paola (2003) developed a cellular model that distributes water across cells in each time step according to the bed topography, and moves sediment between cells according to a local stream power index moderated by sediment availability / retention related to cell vegetation. Plants grow until they are destroyed by either excessive deposition or erosion. The model was used to examine the impact of sediment stabilization by plants on channel pattern, particularly the transition from multi- to single-thread patterns. Crosato and Saleh (2010) also explored the effects of floodplain vegetation (grass) on river planform using a model scaled to the River Allier, France, upstream of Moulins. The model incorporates the effects of vegetation on flow velocity, bed shear stress and sediment transport, and allows vegetation to colonise bare sediment that is exposed during low water stages. Over a simulation equivalent to 10 years of channel development under a characteristic annual flow regime, the model generated a braided planform in the absence of vegetation and a meandering planform with vegetation. In a more detailed meander migration model that incorporates vegetation-mediated processes of bank erosion and accretion, Parker et al. (2010) have taken account of processes on the outer, eroding (slump block toe protection) and inner, depositing (vegetation colonization of deposited sediment) banks, with the separate modeling of the two banks linked through morphodynamic evolution of the central part of the channel. Finally, in a sequence of papers, increasingly sophisticated models of vegetation colonization and growth in response to river flows and floodplain groundwater levels (Camporeale and Ridolfi, 2006), have been linked to a fluid dynamical model of meander development to induce complex spatial patterns in floodplain vegetation biomass (Perucca et al., 2006), and then the feedback effect of the distribution of biomass on mechanical properties of river banks and thus on meander evolution (Perucca et al. 2007). Further modeling has demonstrated that these interactions between vegetation, discharge and the hydraulic character of the channel-floodplain cross-profile have major impacts on 
longitudinal dispersion processes during over-bank floods and thus longitudinal transport along rivers (Tealdi et al., 2010).

In summary, important geomorphologically-relevant outcomes from recent modeling work include recognition of the influence of vegetation on river planform and planform dynamics including the impact of vegetation on both eroding and depositing banks. Models have incorporated a range of vegetation-related factors including canopy flow resistance, rootreinforcement of sediment reflecting both root mechanical properties and architecture; constraints of plant burial and erosion; and also moisture-dependent plant growth.

\section{Recent advances: Field Observations}

As modeling and flume experiments have become more sophisticated they have provided confirmation of the biogeomorphological importance of phenomena that had been inferred previously from field observations; they have placed these phenomena on a sound theoretical footing; and they have enabled their scale-dependence to be explored. At the same time, field research has continued to investigate processes and related landforms in detail across a range of environmental settings and to propose new phenomena that are worthy of investigation through flume experimentation and modeling. This field research relates to four broad and, to some extent, overlapping themes, which explore the importance of vegetation for bank processes; multi-thread river styles; sediment retention; and pioneer landform development.

Research on vegetation and bank processes has remained an important focus for field investigation. In relation to broad bank vegetation cover classes, Micheli et al. (2004) estimated that agricultural floodplains were $80-150 \%$ more erodible than forested ones and Allemendinger et al. (2004) found that vegetation-mediated deposition and lateral channel migration are both higher along non-forested reaches than forested reaches, leading to wider equilibrium channel widths at the forested sites that they observed in Pennsylvania.

Many field studies have revealed important spatio-temporal variations in riparian plant rooting depths and structures that are important for bank stability. For example, Kiley and Schneider (2005) identified both spatial and distinct seasonal variations in the depth distribution of riparian root biomass along streams in the Adirondacks, USA; Abernethy and Rutherford (2001) found that interspecies differences in root distribution between Australian riparian tree species were highly significant for bank reinforcement; Rutherfurd and Grove (2004) found that some riparian trees could offer strengthening through to the base of river banks as high as $4 \mathrm{~m}$; Wynn et al. (2004) identified great variability in root architecture and size distribution with depth between, but also within, herbaceous and forested sites in headwater stream 
banks in Virginia; and Docker and Hubble (2008) showed that tree roots fail progressively rather than simultaneously, so that estimates of shear strengths that assumed simultaneous root failure were on average $50-215 \%$ greater (according to tree species) than measured values.

Field studies have also investigated the importance of both above and below ground vegetation properties for bank stability / erosion. Pizzuto et al. (2010) evaluated the rate and variance in river bank retreat associated with tree size and spacing and the development of a scalloped bank planform dictated by tree buttressing, undercutting and toppling. Based mainly on field observations, McBride et al. $(2008,2010)$ proposed a conceptual model of channel incison, widening and recovery as stream banks develop a riparian forest cover.

Measurements during floods on forested and non-forested reaches confirmed the significantly higher turbulent kinetic energy in forested reaches that was indicated in their flume experiments (McBride et al., 2007), further contributing to understanding the larger width of forested in comparison with adjacent unforested reaches. Malkinson and Wittenberg (2007) also considered the structure of the above-ground biomass, highlighting the importance of shrubs in reducing flow velocities and thus further contributing to bank stability. Other research that has focused on above-ground biomass includes an evaluation of the effect of tree characteristics as well as substrate conditions on tree bending (Stone et al., 2013) and breakage (Tanaka and Yagisawa, 2009) and interactions between flow and vegetation during flood events. At a reach scale, Toledo and Kauffman (2001) illustrated complex linkages between vegetation, hydrology and geomorphology affecting bank stability / erosion in incising headwater streams in Oregon. Channel incision affected bank hydrology and inundation frequency, leading to a change in bank vegetation from wetland to drier environment species, with an accompanying reduction in root biomass and rooting depth, from which a positive feedback of further channel incision and widening was inferred. Although not related to bank stability analysis, Stallins et al. (2010) describe and Loheide and Booth (2011) model interactions and feedbacks between soil moisture-groundwater hydrology, surface water inundation, floodplain form, and vegetation composition and distribution that could equally affect channel lateral dynamics through changes in the species composition of riparian vegetation and the structure of above- and below-ground biomass.

Researchers have also continued to explore relationships between riparian vegetation and multi-thread river systems, but with greater emphasis on vegetation-mediated processes. Complex processes of channel adjustment involving large wood accumulations and living trees have been identified in rivers in the Pacific Northwest of the USA (e.g. Abbe and Montgomery, 2003; O'Connor et al., 2003; Brummer et al., 2006; Montgomery and Abbe, 2006; Collins et al., 2012), including the development of islands, wood and vegetation controlled avulsions, and wood-reinforced erosion-resistant hard spots within floodplains. Similar processes dependent on resprouting of deposited wood and riparian tree colonization 
have been identified in European rivers (e.g. Gurnell et al., 2001; Gurnell and Petts, 2006; Corenblit et al., 2010; Welber et al., 2012). Studies of riparian woodland have also shown how forest structure and wood retention on floodplains influences over-bank flow pathways and side-channel development (e.g. Sear et al. 2010); sediment and organic matter retention (Jeffries et al., 2003; Cierjacks et al., 2011); and how the physical structure and composition of the understorey vegetation is in turn affected by disturbance magnitude and frequency (Dufour and Piégay, 2010).

One important emerging theme has been the impact of vegetation on the hydraulic efficiency of dryland river channels (e.g. Tooth, 2000; Tooth and Nanson, 2000; Tooth and McCarthy, 2004a; Tooth et al., 2007; Pietsch and Nanson, 2011). In these systems, trees growing on river channel beds trap sediment during flow events leading to the formation of stable ridgeshaped islands that funnel flows through anabranching channel systems adjusted to the efficient transfer of water and sediment. The geometry of these vegetated anabranching systems differs strongly from perennially flowing systems (Pietsch and Nanson, 2011) and over time they tend to propagate downstream as upstream sections transmit sediment increasingly efficiently, providing fresh downstream sediment surfaces for vegetation to colonize and initiate new anabranches (Tooth et al., 2007). Close interactions between vegetation and channel cross-profile efficiency have also been recognized in perenniallyflowing, low energy, organic wetland systems (Gradzinski et al., 2003; Tooth and McCarthy, 2004b; Watters and Stanley, 2007; Nanson et al., 2010) and densely vegetated, sand-bed tropical systems (Jansen and Nanson, 2010). In organic wetland systems, dense emergent aquatic and riparian vegetation grows on deep organic sediment that forms the margins and sometimes also the bed of river channels. In these frequently multi-thread, anastomosing systems, the vegetation and organic sediment not only strongly influence the low width to depth ratio of channel cross profiles but they are also dependent on the maintenance of a high water table, which is itself dependent on the geometry and drainage efficiency of the channel system. Vegetation is similarly influential within the anabranching channels of the sand-bed Magela Creek, northern Australia (Jansen and Nanson, 2010). Here channels have a low width to depth ratio reinforced by dense riparian vegetation consisting of 'colonnades of trees that simulate a vegetation-walled corridor' protecting the banks from erosion and impeding exchange of momentum between the channel and floodplain during overbank flows.

Interactions between vegetation and fluvial processes have also been shown to have significant effects on mineral sediment transfer and local sediment storage. These impacts are particularly noticeable when there is a significant change in fluvial processes and/or vegetation. Research comparing the Cann River, which has been strongly affected by changes in riparian vegetation cover and land management following European settlement, with the relatively pristine Thurra River, SE Australia (Brooks and Brierley, 2002; Brooks et al., 2003) showed the crucial role of wood and trees for maintaining rivers in a 'mediated 
equilibrium' condition with high sediment retention; and the enormous impact (7x increase in channel capacity, 3.6x increase in channel depth; 150x increase in lateral channel movement) of wood and tree removal. The importance of woody riparian vegetation for floodplain stability and sediment retention is also illustrated by its role in preventing floodplain unraveling (i.e. sudden widening of the river channel across the floodplain) during major floods in systems that are close to a transition from single- to multi-thread planform (Griffin and Smith, 2004; Smith, 2004).

In the context of rivers recovering from riparian vegetation removal, Zierholz et al. (2001) noted how, following a period of intense gullying and channel bed incision, colonization of $25 \%$ of the channel network of the Jugiong Creek catchment, SE Australia since 1945 by emergent macrophytes, has resulted in the trapping of 2,000,000 tonnes of sediment, equivalent to 4.7 years of sediment production from this $2175 \mathrm{~km}^{2}$ catchment. Erskine et al. (2012) documented how such adjustments reflect complex interactions between several biogeomorphic processes. Following extreme channel widening of the Widden Brook, Hunter Valley, Australia, as a result of a combination of frequent floods and riparian vegetation clearance by European settlers, channel narrowing occurred in the second half of the $20^{\text {th }}$ century through (i) the colonization of marginal bars by riparian trees and grasses that trapped sediment, aggrading the bar surfaces to form benches (for a detailed description see Erskine et al., 2009), and (ii) smaller-scale accretion of banks and chutes as a result of sediment trapping and stabilisation by stoloniferous and rhizomatous grasses.

Channel narrowing and sediment retention related to riparian and aquatic vegetation colonization and growth have been observed in many environmental contexts both as recovery mechanisms between extreme flow events or in response to climate- or humaninduced changes in the river flow regime (e.g. Friedman and Lee, 2002; Ollero, 2007; Garófano-Gómez et al., 2012). Many of these interactions have involved invasions by alien plant species that take advantage of the changed hydrological conditions and thus the removal of key elements of the flow regime that maintain the native vegetation (Stromberg, 2001; Shafroth et al., 2002; Stromberg et al., 2007, 2010). The invasion of US floodplains by Tamarix spp., often accompanied by other aliens such as Russian olive (Elaeagnus angustifolia) and Giant cane (Arundo donax), provides many well-documented examples of large-scale sediment retention, channel narrowing and stabilisation (e.g. Birken and Cooper, 2006; Cadol et al., 2011; Dean and Schmidt, 2011). Conversely, removal of Tamarix spp. has resulted in the release of enormous quantities of sediment. For example, the application of herbicides along a $12 \mathrm{~km}$ reach of the Rio Puerco, New Mexico, resulted in erosion of $680,000 \mathrm{~m}^{3}$ of sediment and an $84 \%$ increase in channel width during a single flood (Vincent et al., 2009). 
A final theme of field research concerns the processes by which plants initiate landforms within fluvial systems. This topic is the focus of a later section of this paper. At this stage it is important to stress that pioneer landforms created by individual plants or plant patches, sometimes in association with dead wood, are being identified in many fluvial systems at the interface between areas within the cross and long profile of the river where physical processes dominate and areas where plants dominate the character of the fluvial corridor. Examples include wood piles (e.g. Pettit et al., 2006), dead (Abbe and Montgomery, 2003) and sprouting deposited riparian trees (e.g. Edwards et al., 1999; Gurnell et al., 2001, 2005) and tree fragments (e.g. Rood et al., 2011); and emergent (e.g. Asaeda et al., 2010; Liffen et al., 2011) and submerged aquatic plants (e.g. Cotton et al., 2006). These plants and the pioneer landforms that they induce by trapping and stabilising sediment, organic matter and the propagules of other plant species, facilitate the rapid establishment of other plants that can in turn reinforce the development of the vegetated landforms. In aggregate, these small features have a significant impact on the outcomes of interactions between vegetation and fluvial processes, contributing to characteristic 'fluvial biogeomorphic successions' (Corenblit et al., 2007; 2010) in different environmental settings.

Overall field investigations of vegetation within fluvial systems over the last 15 years have revealed that vegetation has a far more important and complex role than previously realised, and that this role is significant across space scales from individual plants to entire forested river corridors. Moreover, this role varies continuously through time as above and below ground biomass change within the annual growth cycle, over longer term growth trajectories, and in response to external drivers, particularly those relating to climatic, hydrological and fluvial fluctuations and extremes.

\section{Physical environmental controls on vegetation within river corridors}

The degree to which plants impact on fluvial systems is constrained by the environmental setting. Ultimately climate constrains the species that are able to grow at a site, and as a result, different species of riparian and aquatic plants thrive in different environments. A few of these species have the ability to colonise and grow vigorously within heavily disturbed areas of the river corridor. For example, along the Tagliamento River, Italy, three riparian tree species dominate the riparian zone (Alnus incana, Salix eleagnos, Populus nigra) with their presence and relative cover changing along the river's course as the climate shifts from Alpine in the headwaters to Mediterranean in the lower reaches (Figure 1A). Different species can take on similar geomorphological roles in different environmental settings, and within a particular climatic context, physical (hydrological and fluvial) processes (Figure 2) heavily influence the survival, composition and growth performance of the riparian and aquatic plants that are present. At a reach scale, the structure and development of riparian plant 
communities is largely controlled by the flow regime (Pettit et al., 2001; Stromberg, 2001; Nilsson and Svedmark, 2002; Dynesius et al., 2004; Lytle and Merritt, 2004; Lite et al., 2005; Rood et al., 2003a, 2005, García-Arias et al., in press) both directly and through the cascade of physical processes that it influences including the moderation of riparian groundwater conditions. Aquatic plants also respond strongly to fluvial controls (e.g. Riis and Biggs, 2003; Baattrup-Pedersen et al., 2006; Daniel et al., 2006). Evidence for this at a national scale is provided in Figure 3, which incorporates information on the abundance of over 100 aquatic plant species surveyed in 467 river reaches across Great Britain. When these species are grouped into five morphotypes (i.e. grouped according to plant morphology) and a canonical correspondence analysis is performed on morphotype abundance in relation to reach physical properties, clear patterns emerge in the morphological structure and abundance of aquatic plants associated with reaches of different flow energy and substrate calibre (Gurnell et al., 2010).

River flows govern a gradient of physical environment properties as their energy increases. In low energy environments the key flow properties are largely hydrological, including water depth in permanently inundated areas and inundation duration and frequency, near-surface groundwater regimes (including frequency and duration of inundation / waterlogging), and moisture availability within the riparian zone. All of these properties constrain the composition of aquatic and riparian plant communities. Aquatic species require inundated habitats and, even in still water environments, are sensitive to water depth and clarity (e.g. Fischer and Claflin, 1995; Sharp et al., in press). In the flowing waters of Danish streams, Riis et al. (2000, 2001) also found that the composition of aquatic vegetation varied with channel width and water quality as well as with stream depth. At the transition between aquatic and riparian zones, water availability becomes particularly influential since aquatic plant communities show widely varying abilities to cope with and recover from periods of dry conditions (Holmes, 1999). Naturally-functioning riparian zones exhibit a wide range of hydrological conditions, not only reflecting spatio-temporal variations in hydrological processes but also the moisture retentiveness of complex alluvial substrates, whose calibre is in turn affected by the energy of the river that deposited them. Different riparian plant species have different tolerances and growth responses to hydrological conditions, with studies of riparian trees revealing speciesspecific responses to levels and extremes in soil moisture and depth to water table, as well as frequency and duration of inundation. In this context, a review by Glenz et al. (2006) is particularly informative, since it presents a conceptual model of how riparian trees respond to flooding and then classifies 65 European tree and shrub species according to their inundation tolerance. Research studies of particular riparian species and physical processes have also revealed community and species-specific tolerances and growth responses to inundation and flood disturbance (e.g. Bren, 1988; Auble et al., 1994, Blanch et al., 1999, Friedman and Auble, 1999; Amlin and Rood, 2001, 2002, 2003; Pettit et al., 2001; Predick et al., 2009) as well as to groundwater levels and drought stress (Amlin and Rood, 2002, 2003; An et al., 
2003; Naumberg et al., 2005; Loheide and Gorelick, 2007; Imada et al., 2008; Mouw et al., 2009; Lowry and Loheide, 2010; González et al., 2012; Singer et al., in press).

Flow disturbance and related mobilization and deposition of sediment impose drag on plants, affect stability of the substrate into which the plants are rooted, and subject plants to scour, excavation, uprooting and burial (Figure 2). These physical constraints on the vegetation increase in severity with increasing flow energy. At the same time, mobilization and sorting of increasingly coarse sediment can feed back into the creation of moisture extremes within riparian zones. Coarse sediment patches drain efficiently, giving rise to moisture conditions that can range from waterlogged to intensely arid as river stage fluctuates. Overall river corridors present highly disturbed, extreme environments exhibiting immense spatial and temporal variations in moisture availability, flow and substrate conditions and sediment dynamics. As a result, river corridors are characterized by complex, temporally dynamic spatial distributions of plant species associated with a shifting mosaic of habitat patches (Figure 4, Pringle et al., 1988; Stanford et al., 2005; Mouw et al., in press), which broadly reflect relative topographic position and proximity to the main channel (disturbance magnitude and frequency) and sediment calibre (hydrological conditions) within the riparian corridor (e.g. van Coller et al., 1997; Robertson and Augsperger 1999; Bendix and Hupp, 2000; Richter and Richter, 2000; Dixon et al., 2002; Cooper et al., 2003, 2006; Turner et al., 2004; Friedman et al., 2006, Laterell et al., 2006; Robertson, 2006; Nakamura et al., 2007). Biological and chemical processes that also influence the presence and abundance of species are linked to and moderated by these patch environments but also respond to larger, catchment-scale factors (e.g. rock type, land use, catchment species pool).

\section{Traits of plant species and groups that are capable of influencing the geomorphology of fluvial environments}

The species composition and structure of vegetation in fluvial environments is so strongly influenced by fluvial processes and the overall fluvial regime (Richter and Richter, 2000) that researchers have developed models that synthesise the response of individual species and communities to various elements of the fluvial regime (e.g. Bornette et al., 2008). Merritt et al. (2010) specifically considered pioneer species that are the first colonizers of disturbed, bare alluvial substrates. These species exhibit a range of traits relating to reproduction, germination and growth, including adaptations that enable them to survive the high shear stresses and processes of excavation and burial that characterize fluvial corridors. In this context, there has been a particularly strong research focus on riparian tree species (particularly the Salicaceae: willow and poplar species), which are found widely across the northern temperate zone. However, research on other tree species found in riparian zones has also shown them to respond and be well adapted to fluvial processes (e.g. Acer 
saccharinum, Betula nigra, Dixon, 2003; Alnus acuminata, Easdale et al., 2005; Acer negundo, DeWine and Cooper, 2007; Casuarina cunninghamiana, Erskine et al., 2009; Fraxinus excelsior, Dufour and Piégay, 2008). Aquatic plant species also tend to occupy particular ranges of physical and hydraulic habitat conditions (Riis and Biggs, 2003, Haslam, 2006; O'Hare et al., 2010), within which they display many adaptations that support their survival.

\section{Sexual Reproduction}

Because of wide differences in the timing of seed production, and the size, longevity, density/buoyancy, and dispersal pathways utilized by different seed species, plant recruitment through sexual reproduction in fluvial systems is extremely complex. Figure 5 indicates some of the main controls on the species composition of viable seeds deposited within the margins of two British rivers (Gurnell et al., 2008), including the catchment species pool, sampling position within the channel and riparian zone (which reflects the balance between dispersal pathways used by different species), and sampling time (which reflects timing of seed release, seed longevity and the degree to which the seasonal duration and frequency of river levels may have influenced seed delivery by hydrochory).

Production and dispersal of seeds of riparian poplars and willows are well adapted to highly disturbed fluvial environments (Karrenberg et al., 2002). These tree species produce enormous quantities of very small, light, short-lived seeds. For example, a study of six Salicaceae species (Populus nigra, Salix alba, S. daphnoides, S. elaeagnos, S. purpurea, and S. triandra) by Karrenberg and Suter (2003) established that, according to species, individual plants produced between $10^{3}$ and $10^{6}$ seeds, seed weight ranged from 0.02 to $0.8 \mathrm{mg}$, and the viability of $50 \%$ seeds was lost in a period of between 6.5 and 23.3 days. The seeds of different species of the Salicaceae are produced within short time windows throughout spring and early summer and are widely dispersed by both wind and water. The time of seed release is attuned to the natural annual river flow regime of high flows in the late winter and early spring, since successful germination of these species requires a moist, bare substrate, and early growth is supported by gradual water table decline, preferably within moisture-retentive sediment (e.g. Francis et al., 2005; Guilloy et al., 2011). While dispersal by wind may allow some seed to reach suitable germination sites, secondary dispersal by water concentrates deposition along the water's edge during spring to summer falling river stages, where moisture and bare sediment are abundant. Because physical conditions are so important for germination and early growth of the Salicaceae, Mahoney and Rood (1998) were able to define a 'recruitment box', linking the timing of seed release, germination and early growth to the level and rate of recession of river stage, and so allowing estimation of whether recruitment of particular species is likely to be successful in a particular year. This modelling 
approach has been developed subsequently to investigate recruitment of different riparian trees species under both natural and prescribed flow regimes (e.g. Rood et al., 2003a, 2005; Lytle and Merritt, 2004; Ahna et al., 2007).

\section{Asexual Reproduction}

Pioneer plant species in river environments also devote considerable resources to asexual reproduction. This form of reproduction can occur at any time, spreading the risk of encountering unfavourable recruitment conditions, although widespread dispersal of vegetative fragments is associated with floods. Vegetative propagules usually benefit from greater internal resources than seeds to support their initial growth, and so they tend to cope with a wider range of environmental conditions and to grow faster. A mix of sexual and asexual reproduction can lead to successful recruitment of the same species at different locations during the same time period (e.g. Asaeda et al., 2011).

In the case of the Salicaceae, vegetative reproduction can be highly successful whether small plant fragments or entire uprooted trees are involved (e.g. Asaeda et al., 2011). Rood et al. (2003b) describe a process whereby branches are sheared off riparian trees during transport by flood waters and, following deposition in a favourable location, the branches sprout to form vigorous saplings. Gurnell et al. $(2001,2005)$ recognised uprooted, deposited trees as being the key propagules supporting rapid regeneration along the Tagliamento River, Italy. Since floods are needed for trees and large living wood pieces to enter the river, it is likely that this 'living wood' (Gurnell et al., 2001) will be deposited on relatively elevated, bare, moist alluvial sediment during flood recessions, promoting rapid sprouting and the potential for significant root and shoot growth before further flood disturbance (Edwards et al., 1999, Gurnell et al., 2005). As with seed germination, deposition on an open, moist substrate is crucial for regrowth of the Salicaceae (Francis, 2007).

Like riparian plants, aquatic plant species also employ both sexual and asexual reproduction. Asexual reproduction is very important for expanding cover locally and for coping with major flow disturbances (Riis and Sand-Jensen, 2006). In humid temperate environments, these species tend to follow an annual growth cycle (Figure 6), whereby shoots emerge in the spring, achieve peak biomass in mid to late summer and then senesce during Autumn, leaving little (if any) above-ground biomass during winter (Figure 6B). Many aquatic species produce dense networks of rhizomes that support vegetative reproduction. Shoots and roots develop from nodes on the rhizomes, allowing plant stands to extend laterally during favourable conditions. Rhizomes persist through the winter, retaining and reinforcing colonised sediment (Figure 6A). During severe floods, particularly during winter when there is negligible foliage to provide flow resistance and little root biomass (Figure 6B), rhizome- 
reinforced sediment patches can become scoured or undermined, exposing rhizomes (Figure $6 \mathrm{~F})$ to breakage and the formation of mobile propagules that can colonise downstream sites.

\section{Growth Rate}

An ability to grow rapidly is also crucial for plant survival within fluvial systems. Riparian tree species grow rapidly in suitable environmental, particularly hydrological, conditions. The development of above-ground biomass provides a simple measure of plant growth performance. Figures $1 \mathrm{~B}$ to $\mathrm{D}$, illustrate annual growth increments in one riparian tree species (Populus nigra) on open areas of gravel bars along the middle to lower reaches of the Tagliamento River. Annual increments in plant height vary according to moisture availability, particularly reflecting groundwater levels in the alluvial aquifer, and show increasing growth rates (i) where groundwater upwelling and tributary inputs occur (e.g. from ca 74 to $81 \mathrm{~km}$ and downstream from $104 \mathrm{~km}$ ), (ii) where individuals are more established and thus have deeper and more extensive root systems (compare annual average seedling (Figure 1B) and 3m tall shrub (Figure 1C) growth increments measured in 2005), and (iii) through time as moisture availability varies (compare average annual growth increments of $3 \mathrm{~m}$ tall shrubs in 2005 (Figure 1C), following two years with predominantly low baseflow river stages (Figure 7), and in 2010 (Figure 1D), following a period of two years with predominantly high baseflow river stages (Figure 7)). Furthermore, initial growth varies strongly at the same site according to propagule type (Figure 8). Despite their relatively fast growth rates in comparison with other shrub and tree species, Populus nigra seedlings grow more slowly than vegetative propagules and large vegetative propagules growing more rapidly than smaller ones under the same environmental conditions (Figure 8). As a result, seedling survival is relatively low during the first year of growth. For example, Johnson (2000) monitored the fate of 37,000 Salicaceae seedlings during a 14 year study along the Platte River, USA. He found that seedling mortality was heavily affected by erosion or burial during summer flow pulses, dessication during summer low flows, and river bed restructuring by ice during winter, with all seedlings dying in over $40 \%$ of measurement plots by September of the germination year and in approximately $90 \%$ of plots within the first twelve months.

Measurements of below-ground biomass demonstrate that root and shoot development in the Salicaceae are both strongly attuned to hydrological conditions. Young plants show rapid root development that tracks the falling water table and root architecture that is strongly influenced by groundwater levels and fluctuations (e.g. Mahoney and Rood, 1998, Kranjcec et al., 1998; Francis et al., 2005; Imada et al., 2008; Pasquale et al., 2012). For example, Francis et al. (2005) observed average daily increments in rooting depth of between 20 and $27 \mathrm{~mm}$ for Salix eleagnos and 10 and $15 \mathrm{~mm}$ for $P$. nigra, for a $3 \mathrm{~cm}$.day ${ }^{-1}$ rate of water table decline, with variations for each species depending upon substrate calibre. Such fast rates of root 
extension allow young plants to gain rapid root anchorage, which helps them to resist uprooting by fluvial disturbances.

In the case of aquatic plants in humid temperate environments, the annual growth cycle ensures that plants expose the lowest above-ground biomass at times of highest (winter) flows. Although some species are annuals, many aquatic species are perennial, usually sprouting in spring to achieve peak above-ground biomass in mid to late summer and then dying back in the autumn. Below-ground biomass also follows an annual growth and decay cycle. For example, Sparganium erectum, a very common emergent aquatic plant (Riis et al., 2000; O'Hare et al., 2010) that is found across much of the northern temperate zone, maintains a network of rhizomes throughout the year but shows rapid root growth in spring, slightly in advance of above-ground biomass (Figure 6B), with dense roots extending up to 40 $\mathrm{cm}$ in length by mid-summer, and a cycle in rhizome growth that is slightly later, ensuring that rhizome density is highest in late summer, with up to 10 rhizomes per plant.

\section{Adaptation to Flow, Erosion and Burial Stresses}

A final set of plant adaptations to fluvial environments concern their morphological responses to stream flow variations and their ability to withstand burial and uprooting. Young plants of the Salicaceae not only develop above- and below-ground biomass rapidly, but their stems and branches are very flexible. Figure 9 shows different degrees of canopy deformation and both fine sediment deposition (Figure 9B) and scour (Figure 9D) around dense strips of Salix eleagnos seedlings, following a summer flood on the Tagliamento River, Italy. As the Salicaceae mature, some species (e.g. Salix eleagnos) develop a bushy morphology and retain considerable stem and branch flexibility, whereas others grow taller, and develop rigid trunks (e.g. Populus nigra, Figure 10C). In both cases, they develop robust and extensive root networks (Figure 10) that strongly resist uprooting (e.g. Karrenberg et al, 2003b) and whose morphology and biomass adjusts to mechanical stresses (Scippa et al., 2008). The roots anchor plants into gravel bar surfaces (Figure 10B), and reinforce sediment that is retained within plant stands (Figure $9 \mathrm{~B}$, Figure $10 \mathrm{~A}$ and $\mathrm{C}$ ). The production of deep root systems and also of adventitious roots in response to burial (Figure $10 \mathrm{C}$ ) are particularly important for these species as they help them to avoid being undermined by bank erosion (Figure $10 \mathrm{~A}$ and C) and give them a very high tolerance to burial (Figure 9C).

Most aquatic plant species also show high resistance to fluvial damage including uprooting as a result of a variety of traits (Schutten and Davy, 2000; Schutten et al., 2005). Different plant morphotypes have different aggregate impacts on flow resistance (Bal et al., 2011) and interact with flowing water in different ways (Sand-Jensen and Pedersen, 1999; Green 2005), but in general submerged macrophyte species adopt a streamlined morphology that reduces 
drag (Sand-Jensen, 2008; Sand-Jensen and Pedersen, 2008; Dijkstra and Uittenbogaard, 2010) whereas many erect emergent macrophytes present relatively higher local flow resistance and show remarkable mechanical strength in both above and below-ground organs, allowing them to resist breakage and uprooting. For example, biomechanical measurements of the emergent macrophyte Sparganium erectum have shown that while its rhizomes persist and show considerable strength with only relatively small seasonal variations, its stems, rhizomes and roots are all very robust by mid-summer (Liffen et al., 2011). Numerical modelling indicates that as a result of the strength of Sparganium erectum, lateral erosion and undermining of stands is the only mechanism that is likely to dislodge plants in the generally low energy river environments that this species occupies (PollenBankhead et al., 2011). Different morphologies, and stem and stand densities of aquatic macrophytes are associated with different impacts on the flow field (Folkard, 2009) and thus their sediment trapping and retention potentials (Sand-Jensen, 1998; Clarke, 2002; Schulz et al., 2003; Sharpe and James, 2006). Some submerged species are adversely affected by sedimentation and so they only tend to survive in locations where sediment supply is relatively low and / or where their interactions with the flow field do not support significant sediment retention. However, individuals and stands of many submerged and most emergent species form effective sediment retention structures (Cotton et al., 2006; Gurnell et al., 2006; Asaeda et al., 2010; Neary et al., 2011). Whilst sediment may be resuspended (Kleeberg et al., 2001), particularly following decay of the above-ground biomass through the winter, some species develop below ground organs (roots, rhizomes etc.) within the retained sediment that both anchor the plants during the growing season and retain and reinforce the sediment through the winter. These are the species that are geomorphologically significant.

\section{How plants influence river form and dynamics}

It is clear from the above review of vegetation as a control on alluvial river behaviour, that vegetation influences channel size, pattern and dynamics at a macro-scale. This section is concerned with how plants achieve this influence at the local scale in different environmental contexts.

Hotspots of river ecosystem engineering by plants

The mechanisms by which plants survive in fluvial corridors and influence geomorphology were summarized in the previous section. In essence, particular species can survive only inside specific envelopes of physical environmental conditions, which vary according to the broad climatic and physiographic context and local spatio-temporal variations in the magnitude and frequency of fluvial processes (e.g. Gurnell and Petts, 2006). At any particular 
site, fluvial processes are the primary controls on fluvial morphology, but where conditions are suitable, particular plant species are capable of colonizing exposed or inundated alluvial sediment and then trapping and stabilizing sediment to build pioneer landforms. The plants and the landforms they create, change local physical conditions and trap plant propagules, facilitating colonization and growth of other plant species. In this way, plants influence fluvial geomorphology and act as ecosystem engineers.

At any site, strong lateral gradients in fluvial energy and disturbance exist across river corridors from the low flow channel to the floodplain. The environmental envelope in which ecosystem engineering plants operate is confined between the central areas of the river corridor where fluvial disturbances are too high (Figure $11 \mathrm{~A}$, upper graph, dashed line), and outer areas where competition with other plant species is too strong (Figure $11 \mathrm{~A}$, upper graph, solid line). The area of the corridor located within this envelope can be considered a hotspot of plant ecosystem engineering where particular pioneer plant species interact strongly with fluvial processes (Figure 11A, upper graph shaded area). Depending upon the energy of the river system, the hotspot might be within the low flow river channel, with aquatic plants engineering the form of the bed and bank toe, or it might be beyond the low flow channel, where riparian plants engineer areas of exposed sediment (Figure 11A, lower graph). As river energy increases, the hotspot shifts (Figure 11B) from (i) the channel, where bed siltation around submerged and emergent plants may (a) aggrade the entire river bed, transforming it into a wetland, or (b) create mounds and ridges on the bed, that may eventually aggrade into vegetated bars, to (ii) the low flow channel margins, where emergent aquatic plants trap sediment to form submerged shelves, to (iii) the exposed edges of the low flow channel where seedlings may mature, creating exposed shelves and levée forms, to (v) exposed bar surfaces, where snagged trees and large wood accumulations can sprout and trap sediment forming scroll bars or pioneer islands. All of these pioneer landforms are centred on one or more pioneer plant species, and have a characteristic morphology resulting from interactions between the retention and reinforcement of sediment by the plants and fluvial processes of sediment transport, erosion and deposition (Gurnell, 2007).

Where conditions are suitable for the creation of pioneer landforms, they interact with one another through biogeomorphic feedbacks to maintain a dynamic landform assemblage, as suggested by Schoelynck et al. (2012) in relation to patches of aquatic vegetation, by Larsen et al. (2009) in relation to the maintenance of ridge and slough landforms and communities in the Everglades, and by Francis et al. (2009) in relation to pioneer islands. These biogeomorphic feedbacks may involve the growth and coalescence of pioneer landforms into larger features, but within the hotspot, they may also suffer dissection and erosion. However, towards the edges of the hotspot or as a result of changes in the position of the hotspot related to the spatial and temporal dynamics in fluvial processes, pioneer landforms may be lost from some areas and may evolve into larger landforms (e.g. benches, lateral bank 
extensions, islands, and lateral floodplain extensions, Figure 11B) contributing to the larger scale morphodynamics of the river system. Where major changes in fluvial processes occur, this may be accompanied by changes in the nature of the hotspot and the landformconstructing pioneer species.

A final crucial point is that hotspot character and dynamics are not simply passive responses to fluvial processes. Plants within hotspots create landforms that can only be removed by greater disturbances than those that contribute to their formation. The longer the hotspot persists and the landforms evolve, the greater the disturbance required for landform removal. Therefore, there is a hysteretic relationship between landform construction / destruction and fluvial disturbance. In large river systems, where the hotspots can be large, these interactions and associated landform dynamics can be seen as fluvial examples of the 'self-organized patchiness and catastrophic shifts in ecosystems' described by Rietkerk et al. (2004). Furthermore, the suite of processes and interactions described in this section, which operate at the local scale, fit within the larger scale concept of a 'fluvial biogeomorphic succession' that operates within river corridors (Corenblit et al., 2007).

Vegetation-mediated landform development in different fluvial contexts

This section provides some examples of pioneer and related landforms within the humid temperate zone that are associated with rivers of different gradient, flow energy and sediment calibre.

The Narew River, Poland is a very low energy, anastomosing / anabranching system (Nanson and Knighton, 1996), whose morphodynamics are controlled by vegetation (Gradzinski et al., 2003). Plants provide the material from which the peat channel banks are constructed; reinforcement of these organic river banks; channel encroachment and narrowing; and channel bed colonization and local shallowing (Gradzinski et al., 2003). Submerged and emergent aquatic plants (e.g. Sagittaria sagittifolia, Nuphar lutea) colonise channel beds, whereas the banks are colonized by emergent species (e.g. Phragmites australis). In this system, vegetated bar formation is the key process inducing channel narrowing and change, reflecting colonization, stabilization and subsequent aggradation of the river bed and margins by aquatic plants, particularly the emergent macrophyte, Sparganium erectum. Six bar types are recognized (mid-channel, side, point, concave bank, lingoid and plug) and vegetated bar development and channel blockage by aquatic plants induces elevated water levels, which in turn induce avulsions that create new channels.

The lowland, low energy, predominantly sinuous, single-thread, rivers of southern and eastern England also support many submerged and emergent macrophyte species. In this region, 
three river types with significant aquatic plant communities are recognized: lowland, low gradient; lowland, clay-dominated; and chalk and other base-rich rivers (Holmes et al., 1999). Research on the chalk groundwater-fed, River Frome, Dorset (Gurnell et al., 2006), has established the importance of aquatic plants for trapping fine sediment on the channel bed (Ranunculus spp.; Cotton et al., 2006) and close to the bank toe (Sparganium erectum, Gurnell et al., 2006), and for retaining viable propagules of a wide range of other aquatic, wetland and terrestrial plant species (Gurnell et al., 2007). In the Frome, Sparganium erectum is particularly important for building submerged shelves of sediment along the bank toe. Research on the clay-dominated River Blackwater has revealed the remarkable strength of Sparganium erectum (Liffen et al., 2011) and has identified additional distinct landforms associated with the presence of this species. Fine organic sediment is trapped and retained by the species to form submerged ridges on the channel bed and submerged shelves along the channel margins (the Sparganium erectum stand in Figure $6 \mathrm{C}$ is retaining a point shelf form below the water surface). Once these submerged features aggrade to low flow water level, Sparganium erectum is unable to survive but other species colonise the emerging landform, benefitting from the viable seed bank retained with fine sediment (Figure 6D). A biogeomorphological sequence is set in train, whereby the submerged shelf aggrades to a form a lateral bar or exposed shelf that further aggrades to a bench form and finally to floodplain level. Aggradation is accelerated by sedimentation within the colonizing plants that follow a sequence from emergent to wetland to terrestrial species as the elevation of the landform increases. The entire sequence can be seen in Figure 6E within a sloping bank face landform (black dashed line). This landform is extending laterally into the channel and downstream (towards the foreground) with its submerged leading edge colonized and protected by Sparganium erectum. As the landform develops, the opposite bank erodes, leading to channel migration. In the example shown in Figure $6 \mathrm{E}$, a similar feature forming upstream on the opposite bank is also leading to erosion of the opposing bank and an overall increase in channel sinuosity. Similar, bench features associated with riparian vegetation protection and reinforcement have been described by Erskine et al. (2009) and Rhoads and Massey (2012).

As river energy increases, riparian plants, particularly shrub and tree species, take over the role of fluvial engineers. These species reproduce by both sexual and asexual means. Both propagule types require bare moist sediment for germination and initial growth, but seedlings are more susceptible to damage and removal by fluvial processes, whereas large vegetative propagules, produced in large quantities by severe fluvial disturbances, are able to establish more quickly and so are more resistant to flood damage. Seedlings are most likely to survive and establish at locations or during time periods when fluvial disturbances are relatively small.

Colonisation of the margins of a low flow channel of the braided Tagliamento River by seedlings is illustrated in Figure 9A. Figure 4 (August 2008) shows the same low flow channel 
margins in a broader spatial context, and seedlings can be seen on other channel margins towards the left of the photograph and also along the far side of the river corridor towards the right of the photograph. These strips of seedlings were not present in July 2005 (Figure 4) but developed during a period without major floods between 2005 and 2008 (Figure 7). During this period of subdued flows, the seedlings were deposited, germinated and grew to a height of over $3 \mathrm{~m}$ in some places, but typically to 1.5 to $2 \mathrm{~m}$. The seedling strips trapped varying amounts of sediment during inundation events, but levée-like structures 20 to $40 \mathrm{~cm}$ deep were widespread. Sediment accretion by similar strips has been observed along low flow river margins by Corenblit et al. (2009). In lower energy rivers, these may form the predominant riparian plant-engineered feature, underpinning river bank development where moist sediment is exposed across the lower bank and bank toe to support germination.

In higher energy systems, such as the Tagliamento River, Italy, major fluvial disturbances dislodge and undermine entire trees. These may break up or be deposited whole on gravel bars where they can regenerate. Interactions between this living wood and fluvial processes can lead to elongated features, such as scroll bars or more compact features such as pioneer islands, depending upon the river setting (Gurnell et al., 2001). Along its lower reaches, the Tagliamento River has a low gradient and adopts a meandering planform. Here scroll bars form incorporating large quantities of living wood (Figure 9C). Following deposition, the wood sprouts, generating shrub covered ridges that are gradually incorporated into the floodplain as the river migrates. In the middle and upper reaches of the river, the channel gradient is steeper and the river adopts a braided planform. Whole trees and wood pieces are deposited across braid bar surfaces where they regenerate. Figure 12 illustrates the stages from tree deposition (Figure $12 \mathrm{~A}$ ), through initial sprouting, trapping of sediment, living and dead wood to form pioneer islands (Figure 12, B and D), and then lateral enlargement and, in some cases, coalescence to form larger (building) islands (Figure 12 C, Gurnell et al., 2005). Similar pioneer island development has been observed in many other environments in association with dead wood accumulations (e.g. Abbe and Montgomery, 2003; Pettit et al., 2006; Pettit and Naiman, 2006) and living wood retention on mid channel bars (Rood, et al., 2011). The ability of pioneer islands on the Tagliamento to withstand fluvial disturbances is clearly illustrated in Figure $12 \mathrm{D}$ by the deep scour hole at the island head and significant relief of the island relative to the surrounding bar surface. Pioneer islands are illustrated at a larger spatial scale in Figure 4. Distinct patches of trees associated with pioneer island development can be seen in the middle of the active tract towards the left of the July 2005 photograph and also between the two areas of mature trees in the middle of the active tract towards the right of the same photograph. By August 2008, both of these areas of patchy vegetation in July 2005 had developed to form large islands with continuous tree cover, whereas new pioneer islands had formed close to the edge of the floodplain on the far side of the river. By June 2010, the oldest parts of the island on the left of 2008 photograph had been removed by fluvial processes, 
whereas the floodplain margin on the far side of the river had extended across part of the previous bar surface.

In very high energy systems or where growing conditions do not support sufficiently rapid propagule growth and pioneer island development, river engineering by plants may become confined to the extreme edges of the channel. This explains why extensive, dynamic islands and sequences of scroll bars are confined to those areas of the middle and lower Tagliamento which support the most rapid Populus nigra growth (e.g. between river kilometers 78 to 88 and downstream of 120, Figure 1).

The hysteretic relationship between vegetated landform development and destruction by fluvial processes can also be seen along the Tagliamento River. For example, some of the strip levées formed during the low, subdued flows between 2005 and mid 2008, persisted through floods in late 2008 and 2009 and can still be seen in the June 2010 photograph (Figure 4). This hysteresis has been confirmed at a larger spatial scale by Bertoldi et al. (2011a) through the analysis of multi-temporal ASTER imagery. Between 2004 and 2009, the spatial extent of the vegetated area within the active tract of the river varied through time but also between subreaches of a $20 \mathrm{~km}$ length study reach (including the site shown in Figure 4). At sites where riparian tree growth was vigorous, the vegetated area expanded quickly during periods without large floods, and was subsequently able to resist erosion when floods occurred, whereas at sites where tree growth was slower, the vegetated area expanded at a slower rate and was re-set to its original extent by the floods. By analyzing Lidar data, Bertoldi et al (2011b) were able to show that these different interactions between vegetation and fluvial processes along braided reaches of the Tagliamento affect the entire bed topography of the active tract, with heavily vegetated reaches showing a broad, symmetrical elevation frequency distribution, and sparsely vegetated reaches showing a skewed and peaked elevation frequency distribution. Observations of tree dynamics in these braided reaches has also revealed the relatively short distances moved by large uprooted trees during floods (Bertoldi et al, 2013). This suggests another feedback process between vegetation and geomorphology, whereby the largest trees, which have the potential to create the largest and most vigorous pioneer islands, tend to be deposited on the first bar downstream of the erosion site.

In conclusion, fluvial energy conditions vary downstream along rivers and are reflected in rivers of different planform, suggesting that particular plant engineers and the landforms they create may be associated with rivers of different energy and style (Gurnell et al., 2012). However, fluvial energy also varies laterally within river reaches between main, secondary and side channels on the adjacent floodplain. This suggests that different plant species may affect river morphodynamics by creating different pioneer landforms both between and within river reaches and are likely to play a crucial role at spatial and temporal transitions between 
planforms. These patterns are represented schematically in relation to river planform in Figure 13.

\section{Conclusions}

A combination of field, experimental and theoretical research has resulted in enormous advances in our understanding of the role of vegetation in fluvial geomorphology during the last decade. As modeling and flume experiments have become more sophisticated they have provided confirmation of the biogeomorphological importance of phenomena that had been inferred previously from field observations; they have placed these phenomena on a sound theoretical footing; and they have enabled their scale-dependence to be explored. At the same time, field research has continued to investigate processes and related landforms in detail across a range of environmental settings and to propose new phenomena that are worthy of investigation through flume experimentation and modeling.

The riparian and aquatic plant species present within particular river reaches reflect the broad environmental (particularly climate) setting and local hydrological and fluvial constraints. Nevertheless, within the boundaries set by these constraints, particular species are capable of colonizing exposed or inundated alluvial sediment and then trapping and stabilizing sediment to build pioneer landforms. The plants and the landforms they create trap plant propagules of other species and change local physical conditions, facilitating colonization and growth of other plant species. In this way, individual plants and plant stands / patches influence fluvial geomorphology (land form, relative elevation, sediment calibre etc.). Moreover, different plant species may act as ecosystem engineers creating similar landforms within different environmental settings.

These plant engineers act at the interface between areas of the river corridor dominated by fluvial processes, where plants are unable to survive, and areas dominated by vegetation, where species presence is heavily controlled by competition with other species. In this interface area, individual plants and plant stands / patches play a vital role in influencing the progression / recession of the boundary zone between the active river bed and the floodplain, and affect the character of the fluvial system across space scales from individual plants to entire river corridors. Furthermore, these crucial Interactions between vegetation and fluvial processes vary continuously through time as above and below ground biomass of the engineering species change within the annual growth cycle, over longer term growth trajectories, and in response to external drivers such as climatic, hydrological and fluvial process fluctuations and extremes. 
Despite enormous advances of the last decade, there is still much to be learnt about plants and fluvial geomorphology. To date much research has been pursued within humid temperate environments, which is why these environments have been the main focus of this review. However, as has been indicated, more arid systems have also received significant attention. An important theme for future research is to extend into a wider range of climatic settings.

A second research frontier relates to the spatial and temporal scaling of linkages between vegetation and physical processes. Field researchers are increasingly investigating plant scale phenomena and their variability within annual growth cycles. These small phenomena structure patch-scale geomorphological forms and processes, but interactions between patches are almost certainly crucial to larger scale and longer term geomorphological phenomena. At present we know remarkably little about these scale linkages and the small (time and space) scale phenomena that are most geomorphologically important at larger scales.

Progress in this field is important not only for improving our understanding of how fluvial systems function but also for informing the assessment, sustainable management and restoration of rivers and riparian systems. Plants, plant material, water and sediment interact to create complex fluvial environments and so all of these biological and physical elements need to be incorporated into attempts to restore river environments.

\section{Acknowledgements}

Many thanks to two anonymous referees for their constructive comments, which have greatly helped to improve this manuscript. Numerous colleagues have worked with me on the theme reported in this paper and have profoundly influencing the ideas that I have presented. My sincere thanks go to them all. I also thank the many funding agencies that have allowed me to pursue this research. In particular, I would like to acknowledge three research grants / contracts that are supporting my current research on this theme: Grant F/07 040/AP from the Leverhulme Trust; Grant NE/F014597/1 from the Natural Environment Research Council, UK, and the REFORM collaborative project funded by the European Union Seventh Framework Programme under grant agreement 282656 . 


\section{REFERENCES}

Abbe TB, Montgomery DR. 2003. Patterns and processes of wood debris accumulation in the Queets river basin, Washington. Geomorphology 51: 81-107.

Abernethy B, Rutherfurd ID. 1998. Where along a river's length will vegetation most effectively stabilise stream banks? Geomorphology 23: 55-75.

Abernethy B, Rutherfurd ID. 2001. The distribution and strength of riparian tree roots in relation to riverbank reinforcement. Hydrological Processes 15: 63-79.

Ahna C, Mosera KF, Sparks RE, White DC. 2007. Developing a dynamic model to predict the recruitment and early survival of black willow (Salix nigra) in response to different hydrologic conditions Ecological Modelling 204: 315-325.

Allmendinger NE. Pizzuto JE, Potter N, Johnson TE, Hession WC. 2005. The influence of riparian vegetation on stream width, eastern Pennsylvania, USA Geological Society of America Bulletin, 117: 229-243.

Amlin NA, Rood SB. 2001. Inundation tolerances of riparian willows and cottonwoods. Journal of the American Water Resources Association 37: 1709-1720.

Amlin NA, Rood SB. 2002. Comparative tolerances of riparian willows and cottonwoods to water-table decline. Wetlands 22: 338-346.

Amlin NA, Rood SB. 2003. Drought stress and recovery of riparian cottonwoods due to water table alteration along Willow Creek, Alberta. Trees 17: 351-358.

An SQ, Chen XL, Sun CS, Wang YJ, Li J. 2003. Composition change and vegetation degradation of riparian forests in the Altai Plain, NW China. Plant Ecology 164: 75-84.

Asaeda T, Rajapakse L, Kanoh M. 2010. Fine sediment retention as affected by annual shoot collapse: Sparganium erectum as an ecosystem engineer in a lowland stream. River Research and Applications 26: 1153-1169.

Asaeda T, Gomes PIA, Sakamoto K, Rashid MH. 2011. Tree colonization trends on a sediment bar after a major flood. River Research and Applications 27: 976-984.

Auble GT, Friedman JM, Scott ML. 1994. Relating riparian vegetation to present and future streamflows. Ecological Applications 4: 544-554.

Baattrup-Pedersen A, Szoszkiewicz K, Nijboer R, O'Hare M, Ferreira T. 2006. Macrophyte communities in unimpacted European streams: variability in assemblage patterns, abundance and diversity. Hydrobiologia 566: 179-196.

Bal K, Struyf E, Vereecken H, Viaene P, De Doncker L, De Deckere E, Mostaert F, Meire P. 2011. How do macrophyte distribution patterns affect hydraulic resistances? Ecological Engineering 37: 529-533.

Beeson CE, Doyle PF. 1995. Comparison of bank erosion at vegetated and non-vegetated channel bends. Water Resources Bulletin 31: 983-990.

Bendix J, Hupp CR. 2000. Hydrological and geomorphological impacts on riparian plant communities. Hydrological Processes 14: 2977-2990.

Bennett SJ. 2004. Effects of emergent riparian vegetation on spatially averaged and turbulent flow within an experimental channel. In: Riparian Vegetation and Fluvial Geomorphology,. Bennett SJ, Simon A (eds). American Geophysical Union, Washington D.C., 29-41.

Bennett SJ, Pirim T, Barkdoll BD. 2002. Using simulated emergent vegetation to alter stream flow direction within a straight experimental channel. Geomorphology 44: 115-126.

Bennett SJ, Wu W, Alonso CV, Wang SSY. 2008. Modeling fluvial response to in-stream woody vegetation: implications for stream corridor restoration. Earth Surface Processes and Landforms 33: 890-909.

Bertoldi W, Drake N, Gurnell AM. 2011a. Interactions between river flows and colonising vegetation on a braided river: exploring spatial and temporal dynamics in riparian vegetation cover using satellite data. Earth Surface Processes and Landforms 36: 1474-1486.

Bertoldi W, Gurnell AM, Drake N. 2011b. The topographic signature of vegetation development along a braided river: results of a combined analysis of airborne lidar, colour air photographs and ground measurements. Water Resources Research 47: W06525, 13pp.

Bertoldi W, Gurnell AM, Welber M. 2013. Wood recruitment and retention: The fate of eroded trees on a braided river explored using a combination of field and remotely-sensed data sources. Geomorphology, 180-181: 145-155. 
Birkeland GH. 1996. Riparian vegetation and sandbar morphology along the lower Little Colorado River, Arizona. Physical Geography 17: 534-553.

Birken AS, Cooper DJ. 2006. Processes of Tamarix invasion and floodplain development along the Lower Green River, Utah. Ecological Applications 16: 1103-1120.

Blanch SJ, Ganf GG, Walker KF. 1999. Tolerance of riverine plants to flooding and exposure indicated by water regime. Regulated Rivers: Research and Management 15: 43-62.

Bornette G, Tabacchi E, Hupp C, Puijalon S, Rostan JC. 2008. A model of plant strategies in fluvial hydrosystems. Freshwater Biology 53: 1692-1705.

Braudrick CA, Dietrich WE, Leverich GT, Sklar LS. 2009. Experimental evidence for the conditions necessary to sustain meandering in coarse-bedded rivers. Proceedings of the National Academy of Sciences of the United States of America 106: 16936-16941.

Bren LJ. 1988. Effects of river regulation of flooding of a riparian red gum forest on the river Murray Australia. Regulated Rivers: Research and Management 2: 65-78.

Bren LJ, Gibbs NL. 1986. Relationships between flood frequency, vegetation and topography in a river red gum forest Australian Forest Research 16: 357-370.

Brooks AP, Brierley GJ. 2002. Mediated equilibrium: The influence of riparian vegetation and wood on the long-term evolution and behaviour of a near-pristine river. Earth Surface Processes and Landforms 27: 343-367.

Brooks AP, Brierley GJ, Millar RG. 2003. The long-term control of vegetation and woody debris on channel and flood-plain evolution: insights from a paired catchment study in southeastern Australia. Geomorphology 51: 7-29.

Brummer CJ, Abbe TB, Sampson JR, Montgomery DR. 2006. Influence of vertical channel change associated with wood accumulations on delineating channel migration zones, Washington, USA. Geomorphology 80: 295-309.

Burckhardt JC, Todd BL. 1998. Riparian forest effect on lateral stream channel migration in the glacial till plains. Journal of the American Water Resources Association 34: 179184.

Burylo M, Rey F, Mathys N, Dutoit T. 2012. Plant root traits affecting the resistance of soils to concentrated flow erosion. Earth Surface Processes and Landforms 37: 1463-1470.

Cadol D, Rathburn SL, Cooper DJ. 2011. Aerial photographic analysis of channel narrowing and vegetation expansion in Canyon De Chelly National Monument, Arizona, USA, 1935-2004. River Research and Applications 27: 841-856.

Camporeale C, Ridolfi L. 2006. Riparian vegetation distribution induced by river flow variability: A stochastic approach. Water Resources Research 42: W10415.

Cancienne RM, Fox GA, Simon A. 2008. Influence of seepage undercutting on the stability of root-reinforced streambanks. Earth Surface Processes and Landforms 33: 1769-1786.

Chen S-C, Kuo Y-M, Li Y-H. 2011. Flow characteristics within different configurations of submerged flexible vegetation. Journal of Hydrology 398: 124-134.

Cierjacks A, Kleinschmit B, Kowarik I, Graf M, Lang F. 2011. Organic matter distribution in floodplains can be predicted using spatial and vegetation structure data. River Research and Applications 27: 1048-1057.

Clarke SJ. 2002. Vegetation growth in rivers: influences upon sediment and nutrient dynamics. Progress in Physical Geography 26: 159-172.

Collins BD, Montgomery DR, Fetherston KL, Abbe TB. 2012. The floodplain large-wood cycle hypothesis: A mechanism for the physical and coastal ecoregion. Geomorphology 139140: 460-470.

Cooper DJ, Andersen DC, Chimner RA. 2003. Multiple pathways for woody plant establishment on floodplains at local to regional scales. Journal of Ecology 91: 182196.

Cooper DJ, Dickens J, Hobbs NT, Christensen L, Landrum L. 2006. Hydrologic, geomorphic and climatic processes controlling willow establishment in a montane ecosystem. Hydrological Processes 20: 1845-1864.

Coppin NJ, Richards IG. 1990. Use of vegetation in Civil Engineering, Butterworths, London.

Corenblit D, Baas ACW, Bornette G, Darrozes J, Delmotte S, Francis RA, Gurnell AM, Julien F, Naiman RJ, Steiger J. 2011. Feedbacks between geomorphology and biota controlling Earth surface processes and landforms: a review of foundation concepts and current understandings Earth Science Reviews 106: 307-331.

Corenblit D, Gurnell AM, Steiger J, Tabacchi E. 2008. Reciprocal adjustments between landforms and living organisms: Extended geomorphic evolutionary insights. Catena 73: 261-273. 
Corenblit D, Steiger J, Gurnell AM, Tabacchi E, Roques L. 2009. Control of sediment dynamics by vegetation as a key function driving biogeomorphic succession within fluvial corridors. Earth Surface Processes and Landforms 34: 1790-1810.

Corenblit D, Steiger J. 2009. Vegetation as a major conductor of geomorphic changes on the Earth surface: toward evolutionary geomorphology. Earth Surface Processes and Landforms 34: 891-896.

Corenblit D, Steiger J, Tabacchi E. 2010. Biogeomorphologic succession dynamics in a Mediterranean river system. Ecography 33: 1136-1148.

Corenblit D, Tabacchi E, Steiger J, Gurnell AM. 2007. Reciprocal interactions and adjustments between fluvial landforms and vegetation dynamics in river corridors: A review of complementary approaches. Earth-Science Reviews 84: 56-86.

Cotton JA, Wharton G, Bass JAB, Heppell CM, Wotton RS. 2006. The effects of seasonal changes to in-stream vegetation cover on patterns of flow and accumulation of sediment. Geomorphology 77: 320-334.

Coulthard TJ. 2005. Effects of vegetation on braided stream pattern and dynamics. Water Resources Research 41: W04003.

Crosato A, Saleh MS. 2011. Numerical study on the effects of floodplain vegetation on river planform style. Earth Surface Processes and Landforms 36: 711-720.

Crouzy B, Perona P. 2012. Biomass selection by floods and related timescales. Part 2: Stochastic modeling. Advances in Water Resources 39: 97-105.

Daniel H, Bernez I, Haury J. 2006. Relationships between macrophytic vegetation and physical features of river habitats: the need for a morphological approach. Hydrobiologia 570: 11-17.

Davies NS, Gibling MR. 2009. Paleozoic vegetation and the Siluro-Devonian rise of fluvial lateral accretion sets. Geology 38: 51-54.

Davies NS, Gibling MR. 2010. Cambrian to Devonian evolution of alluvial systems: The sedimentological impact of the earliest land plants. Earth Science Reviews 98: 171-200.

Davies-Colley RJ. 1997. Stream channels are narrower in pasture than in forest. New Zealand Journal of Marine and Freshwater Research 31: 599-608.

Davis RJ, Gregory KJ. 1994. A new distinct mechanism of river bank erosion in a forested catchment. Journal of Hydrology 157: 1-11.

Dean DJ, Schmidt JC. 2011. The role of feedback mechanisms in historic channel changes of the lower Rio Grande in the Big Bend region. Geomorphology 126: 333-349.

Décamps H, Tabacchi E. 1994. Species richness in vegetation along river margins. In: Aquatic Ecology: scale, pattern and process. Giller, PS, Hildrew AG, Raffaelli DG (eds). Blackwell, Oxford, 1-20.

DeWine JM, Cooper DJ. 2007. Effects of river regulation on riparian box elder (Acer negundo) forests in canyons of the upper Colorado River Basin, USA. Wetlands 27: 278-289.

Dijkstra JT, Uittenbogaard RE. 2010. Modeling the interaction between flow and highly flexible aquatic vegetation. Water Resources Research 46: W12547.

Dixon MD. 2003. Effects of flow pattern on riparian seedling recruitment on sandbars in the Wisconsin River, Wisconsin, USA. Wetlands 23: 125-139.

Dixon MD, Turner MG, Jin CF. 2002. Riparian tree seedling distribution on Wisconsin River sandbars: Controls at different spatial scales. Ecological Monographs 72: 465-485.

Docker BB, Hubble TCT. 2008. Quantifying root-reinforcement of river bank soils by four Australian tree species. Geomorphology 100: 401-418.

Dominick DS, O'Neill MP. 1998. Effects of flow augmentation on stream channel morphology and riparian vegetation: Upper Arkansas River basin, Colorado. Wetlands 18: 591-607.

Dufour S, Piégay H. 2008. Geomorphological controls of Fraxinus excelsior growth and regeneration in floodplain forests. Ecology 89: 205-215.

Dufour S, Piégay H. 2010. Channel vertical mobility, hydro-geomorphic disturbances and understory vegetation in floodplain forests of the Ain River (France). GeomorphologieRelief Processus Environnement 4: 371-386.

Dwyer JP, Wallace D, Larsen DR. 1997. Value of woody river corridors in levee protection along the Missouri River in 1993. Journal of the American Water Resources Association 33: 481-489.

Dynesius M, Jansson R, Johansson ME, Nilsson C. 2004. Intercontinental similarities in riparian-plant diversity and sensitivity to river regulation. Ecological Applications 14: 173-191. 
Easdale TA, Sabate S, Grau A. 2005. Don't camp beside the river: structure and dynamics of Andean alder (Alnus acuminata) forests affected by river floods, northwestern Argentina. Revista Chilena de Historia Natural 78: 711-722.

Eaton BC, Giles TR. 2009. Assessing the effect of vegetation-related bank strength on channel morphology and stability in gravel-bed streams using numerical models. Earth Surface Processes and Landforms 34: 712-724.

Eaton BC, Millar RG, Davidson S. 2010. Channel patterns: Braided, anabranching, and single-thread. Geomorphology 120: 353-364.

Edwards PJ, Kollmann J, Gurnell AM, Petts GE, Tockner K, Ward JV. 1999. A conceptual model of vegetation dynamics on gravel bars of a large Alpine river. Wetlands Ecology and Management 7: 141-153.

Erskine W, Chalmers A, Keene A, Cheetham M, Bush R. 2009. Role of a rheophyte in bench development on a sand-bed river in southeast Australia. Earth Surface Processes and Landforms 34: 941-953.

Erskine W, Keene A, Bush R, Cheetham M, Chalmers A. 2012. Influence of riparian vegetation on channel widening and subsequent contraction on a sand-bed stream since European settlement: Widden Brook, Australia. Geomorphology 147-148: 102114.

Fetherston KL, Naiman RJ, Bilby RE. 1995. Large woody debris, physical process, and riparian forest development in montane river networks of the Pacific Northwest. Geomorphology 13: 133-144.

Fischer JR, Claflin TO. 1995. Declines in aquatic vegetation in navigation pool no. 8, upper Mississippi River between 1975 and 1991. Regulated Rivers: Research and Management 11: 157-165.

Folkard AM. 2009. Vegetated flows in their environmental context : a review. Proceedings of the Institution of Civil Engineers: Engineering and Computational Mechanics 164: 3-24.

Francis RA. 2007. Size and position matter: riparian plant establishment from fluvially deposited trees. Earth Surface Processes and Landforms 32: 1239-1243.

Francis RA, Corenblit D, Edwards PJ. 2009. Perspectives on biogeomorphology, ecosystem engineering and self-organisation in island-braided fluvial ecosystems. Aquatic Sciences 71: 290-304.

Francis RA, Gurnell AM, Petts GE, Edwards PJ. 2005. Survival and growth responses of Populus nigra, Salix elaeagnos and Alnus incana cuttings to varying levels of hydric stress. Forest Ecology and Management 210: 291-301.

Friedman JM, Auble GT. 1999. Mortality of riparian box elder from sediment mobilization and extended inundation. Regulated Rivers: Research and Management 15: 463-476

Friedman JM, Auble GT, Andrews ED, Kittel G, Madole RF, Griffin ER, Allred TM. 2006. Transverse and longitudinal variation in woody riparian vegetation along a montane river. Western North American Naturalist 66: 78-91.

Friedman JM, Lee VJ. 2002. Extreme floods, channel change, and riparan forest along ephemeral streams. Ecological Monographs 72: 409-425.

Friedman JM, Osterkamp WR, Lewis WM. 1996. The role of vegetation and bed-level fluctuations in the process of channel narrowing. Geomorphology 14: 341-351.

Friedman JM, Auble GT, Andrews ED, Kittel G, Madole RF, Griffin ER, Allred TM. 2006. Transverse and longitudinal variation in woody riparian vegetation along a montane river. Western North American Naturalist 66: 78-91.

García-Arias A, Francés F, Ferreira T, Egger G, Martínez-Capel F, Garófano-Gómez V, Andrés-Doménech I, Politti E, Rivaes R, Rodríguez-González PM. In press. Implementing a dynamic riparian vegetation model in three European river systems. Ecohydrology.

Garófano-Gómez V, Martínez-Capel F, Bertoldi W, Gurnell A, Estornell J, Segura-Beltrán F. in press. Six decades of changes in the riparian corridor of a Mediterranean river: a synthetic analysis based on historical data sources. Ecohydrology.

Gibling MR, Davies NS. 2012. Palaeozoic landscapes shaped by plant evolution. Nature Geoscience 5: 99-105.

Glenz C, Schlaepfer R, lorgulescu I, Kienast F. 2006. Flooding tolerance of Central European tree and shrub species. Forest Ecology and Management 235: 1-13.

González E, González-Sanchis M, Comín FA, Muller E. 2012. Hydrologic thresholds for riparian forest conservation in a regulated large Mediterranean river. River Research and Applications 28: 71-80. 
Gradzinski R, Baryla J, Doktor M, Gmur D, Gradzinski M, Kedzior A, Paszkowski M, Soja R, Zielinski T, Zurek S. 2003. Vegetation-controlled modern anastomosing system of the upper Narew River (NE Poland) and its sediments. Sedimentary Geology 157: 253-276.

Graf WL. 1978. Fluvial adjustments to the spread of tamarisk in the Colorado Plateau region. Geological Society of America Bulletin 89: 1491-1501.

Graf WL. 1982. Tamarisk and river-channel management. Environmental Management 6: 283-296.

Gran K, Paola C. 2001. Riparian vegetation controls on braided stream dynamics. Water Resources Research 37: 3275-3283.

Gray DH, Sotir RB. 1996. Biotechnical and soil bioengineering slope stabilisation: a practical guide for erosion control, Wiley, New York.

Green JC. 2005. Modelling flow resistance in vegetated streams: review and development of new theory. Hydrological Processes 19: 1245-1259.

Greenway DR. 1987. Vegetation and slope stability. In: Slope Stability. Anderson MG, Richards KS (eds). Wiley, New York, 187-230.

Gregory KJ, Gurnell AM. 1988. Vegetation and river channel form and process. In: Biogeomorphology. Viles H (ed). Blackwell, Oxford, 11-42.

Gregory SV, Swanson FJ, Mckee WA, Cummins KW. 1991. An Ecosystem Perspective of Riparian Zones. BioScience 41: 540-551.

Griffin ER, Smith JD. 2004. Floodplain stabilization by woody riparian vegetation during and extreme flood. In: Riparian Vegetation and Fluvial Geomorphology. Bennett SJ, Simon A (eds). Water Science and Application. American Geophysical Union, Washington, D.C., 221-236.

Guilloy H, Gonzalez E, Muller E, Hughes FMR, Barsoum N. 2011. Abrupt drops in water table level influence the development of Populus nigra and Salix alba seedlings of different ages. Wetlands, 31, 1249-1261.

Gurnell A.M. 1997. The Hydrological and Geomorphological Significance of Forested Floodplains. Global Ecology and Biogeography Letters 6: 219-229.

Gurnell AM. 2007. Analogies between mineral sediment and vegetative particle dynamics in fluvial systems. Geomorphology 89: 9-22.

Gurnell AM. 2013. Wood in fluvial systems. In: Treatise on Geomorphology. Shroder J, Wohl E (eds). Academic Press, San Diego, CA, USA, in press.

Gurnell AM, Bertoldi W, Corenblit D. 2012. Changing river channels: the roles of hydrological processes, plants and pioneer fluvial landforms. Earth Science Reviews 111: 129-141.

Gurnell AM, Goodson J, Thompson K, Clifford N, Armitage PD. 2007. The river bed: a dynamic store for viable plant propagules? Earth Surface Processes and Landforms 32: $1257-1272$.

Gurnell AM, O'Hare JM, O'Hare MT, Dunbar MJ, Scarlett PM. 2010. An exploration of associations between assemblages of aquatic plant morphotypes and channel geomorphological properties within British rivers. Geomorphology 116: 135-144.

Gurnell AM, Petts GE. 2006. Trees as riparian engineers: the Tagliamento River, Italy. Earth Surface Processes and Landforms 31: 1558-1574.

Gurnell AM, Petts GE, Hannah DM, Smith BPG, Edwards PJ, Kollmann J, Ward JV, Tockner K. 2001. Riparian vegetation and island formation along the gravel-bed Fiume Tagliamento, Italy. Earth Surface Processes and Landforms 26: 31-62.

Gurnell AM, Thompson K, Goodson J, Moggridge H. 2008. Propagule deposition along river margins: linking hydrology and ecology. Journal of Ecology 96: 553-565.

Gurnell AM, Tockner K, Edwards PJ, Petts GE. 2005. Effects of deposited wood on biocomplexity of river corridors. Frontiers in Ecology and Environment 3: 377-382.

Gurnell AM, van Oosterhout MP, de Vlieger B. Goodson JM. 2006. Reach-scale interactions between aquatic plants and physical habitat: River Frome, Dorset. River Research and Applications 22: 667-680.

Harris RR. 1987. Occurrence of Vegetation on Geomorphic Surfaces in the Active Floodplain of a California Alluvial Stream. American Midland Naturalist 118: 393-405.

Harwood K, Brown AG. 1993. Fluvial processes in a forested anastomosing river: flood partitioning and changing flow patterns. Earth Surface Processes and Landforms 18: 741-748.

Haslam S. 2006. River Plants, Forrest Text, Tresaith, Cardigan, UK.

Hession WC, Pizzuto JE, Johnson TE, Horwitz RJ. 2003. Influence of bank vegetation on channel morphology in rural and urban watersheds Geology 31: 147-150. 
Hickin EJ. 1984. Vegetation and river channel dynamics. Canadian Geography 28: 111-126. Holmes NTH, Boon P, Rowell T. 1999. Vegetation communities of British Rivers: A revised classification. Joint Nature Conservation Committee, Peterborough, UK.

Hopkinson L, Wynn T. 2009. Vegetation impacts on near bank flow. Ecohydrology 2: 404418.

Huang HQ, Nanson GC. 1997. Vegetation and channel variation; a case study of four small streams in southeastern Australia. Geomorphology 18: 237-249.

Huggenberger P, Hoehn E, Beschta R, Woessner W. 1998. Abiotic aspects of channels and floodplains in riparian ecology. Freshwater Biology 40: 407-425.

Hughes FMR, Harris T, Richards K, Pautou G, Hames AE, Barsoum N, Girel J, Peiry J.-L, Foussadier R. 1997. Woody riparian species response to different soil moisture conditions: laboratory experiments on Alnus incana (L.) Moench. Global Ecology and Biogeography Letters 6: 247-256.

Hughes FMR. 1988. The ecology of african floodplain forests in semi-arid and arid zones - a review. Journal of Biogeography 15: 127-140.

Hupp CR. 1983. Vegetation pattern on channel features in the Passage Creek Gorge, Virginia. Castanea 48: 62-72.

Hupp CR. 1986. Upstream variations in bottomland vegetation patterns, northwestern Virginia. Bulletin of the Torrey Botanical Club 113: 421-430.

Hupp CR, Osterkamp WR. 1996. Riparian vegetation and fluvial geomorphic processes. Geomorphology 14: 277-295.

Imada S, Yamanaka N, Tamai S. 2008. Water table depth affects Populus alba fine root growth and whole plant biomass. Functional Ecology 22: 1018-1026.

Jang CL, Shimizu Y. 2007. Vegetation effects on the morphological behavior of alluvial channels. Journal of Hydraulic Research 45: 763-772.

Jansen JD, Nanson GC. 2010. Functional relationships between vegetation, channel morphology, and flow efficiency in an alluvial (anabranching) river. Journal of Geophysical Research 115: F04030.

Jeffries R, Darby SE, Sear DA. 2003. The influence of vegetation and organic debris on floodplain sediment dynamics: case study of a low-order stream in the New Forest, England. Geomorphology 51: 61-80.

Johnson WC. 1994. Woodland Expansions in the Platte River, Nebraska: Patterns and Causes. Ecological Monographs 64: 45-84.

Johnson WC. 1997. Equilibrium response of riparian vegetation to flow regulation in the Platte river, Nebraska. Regulated Rivers: Research \& Management 13: 403-415.

Johnson WC. 2000. Tree recruitment and survival in rivers: influence of hydrological processes. Hydrological Processes 14: 3051-3074.

Jones CG, Lawton JH, Shachak M, 1994. Organisms as ecosystem engineers. Oikos 69: 373-386.

Karrenberg S, Blaser S, Kollmann J, Speck T, Edwards PJ. 2003b. Root anchorage of saplings and cuttings of woody pioneer species in a riparian environment. Functional Ecology 17: 170-177.

Karrenberg S, Edwards PJ, Kollmann J. 2002. The life history of Salicaceae living in the active zone of floodplains. Freshwater Biology 47: 733-748.

Karrenberg S, Kollmann J, Edwards PJ, Gurnell AM, Petts GE. 2003a. Patterns in woody vegetation along the active zone of a near-natural Alpine river. Basic and Applied Ecology 4: 157-166.

Karrenberg S, Suter M. 2003. Phenotypic trade-offs in the sexual reproduction of Salicaceae from flood plains. American Journal of Botany 90: 749-754.

Kiley D, Schneider R. 2005. Riparian roots through time, space and disturbance. Plant and Soil 269: 259-272.

Kleeberg A, Koehler JAN, Sukhodolova T, Sukhodolov A. 2010. Effects of aquatic macrophytes on organic matter deposition, resuspension and phosphorus entrainment in a lowland river. Freshwater Biology 55: 326-345.

Kochel RC, Ritter DF, Miller J. 1987. Role of tree dams in the construction of pseudo-terraces and variable geomorphic response to floods in Little River valley, Virginia. Geology 15: 718-721.

Kollmann J, Vieli M, Edwards PJ, Tockner K, Ward JV. 1999. Interactions between vegetation development and island formation in the Alpine river Tagliamento. Applied Vegetation Science 2: 25-36. 
Kondolf GM, Curry RR. 1984. The role of riparian vegetation in channel bank stability: Carmel River, California. In: California riparian systems: ecology, conservation, and management. Warner RE, Hendrix KM (eds). University of California Press, Berkeley and Los Angeles, 124-133.

Kondolf GM, Curry RR. 1986. Channel erosion along the Carmel River, Monterey County, California. Earth Surface Processes and Landforms 11: 307-319.

Kranjcec J. Mahoney JM, Rood SB. 1998. The responses of three riparian cottonwood species to water table decline. Forest Ecology and Management 110: 77-87.

Lane EW. 1957. A study of the shape of channels formed by natural streams flowing in erodible material. U.S. Army Corps of Engineers, Missouri River Division, Sediment Series, 9, $106 \mathrm{pp}$.

Larsen LG, Harvey JW, Crimaldi JP. 2009. Predicting bed shear stress and its role in sediment dynamics and restoration potential of the Everglades and other vegetated flow systems. Ecological Engineering 35, 1773-1785.

Latterell JJ, Bechtold JS, O'Keefe TC, Van Pelt R, Naiman RJ. 2006. Dynamic patch mosaics and channel movement in an unconfined river valley of the Olympic Mountains. Freshwater Biology 51: 523-544.

Leopold LB, Wolman MG. 1957. River channel patterns-braided, meandering and straight. U.S. Geological Survey Professional Paper 282B: 39-85.

Li SS, Millar RG. 2011. A two-dimensional morphodynamic model of gravel-bed river with floodplain vegetation. Earth Surface Processes and Landforms 36: 190-202.

Liffen T, Gurnell AM, O'Hare MT, Pollen-Bankhead N, Simon A. 2011. Biomechanical properties of the emergent aquatic macrophyte Sparganium erectum: Implications for fine sediment retention in low energy rivers. Ecological Engineering 37: 1925-1931.

Lite SJ, Bagstad KJ, Stromberg JC. 2005. Riparian plant species richness along lateral and longitudinal gradients of water stress and flood disturbance, San Pedro River, Arizona, USA. Journal of Arid Environments 63: 785-813.

Liu D, Diplas P, Hodges CC, Fairbanks JD. 2010. Hydrodynamics of flow through double layer rigid vegetation. Geomorphology 116: 286-296.

Loheide SP, Booth EG. 2011. Effects of changing channel morphology on vegetation, groundwater, and soil moisture regimes in groundwater-dependent ecosystems. Geomorphology 126: 364-376.

Loheide SP, Gorelick SM. 2007. Riparian hydroecology: A coupled model of the observed interactions between groundwater flow and meadow vegetation patterning. Water Resources Research 43: 16.

Lopez F, Garcia M. 1998. Open-channel flow through simulated vegetation: suspended sediment transport modeling. Water Resources Research 34: 2341-2352.

Lowry CS, Loheide SP. 2010. Groundwater-dependent vegetation: Quantifying the groundwater subsidy. Water Resources Research 46: W06202.

Lytle DA, Merritt DM. 2004. Hydrologic regimes and riparian forests: A structured population model for cottonwood. Ecology 85: 2493-2503.

Mackin J. 1956. Causes of braiding by a graded river. Bulletin of the Geological Society of America 37: 1717-1718.

Madej MA, Weaver WE, Hagans DK. 1994. Analysis of bank erosion on the Merced River, Yosemite valley, Yosemite-National-Park, California, USA. Environmental Management 18: 235-250.

Mahoney JM, Rood SB. 1998. Streamflow requirements for cottonwood seedling recruitment: an integrative model. Wetlands 18: 634-645.

Malkinson D, Wittenberg L. 2007. Scaling the effects of riparian vegetation on cross-sectional characteristics of ephemeral mountain streams-a case study of Nahal Oren, Mt. Carmel, Israel. Catena 69: 103-110.

Marston RA, Girel J, Pautou G, Piégay H, Bravard J-P, Arneson C. 1995. hannel metamorphosis, floodplain disturbance, and vegetation development: Ain River, France. Geomorphology 13:121-131.

McBride M, Hession WC, Rizzo DM. 2008. Riparian reforestation and channel change: A case study of two small tributaries to Sleepers River, northeastern Vermont, USA. Geomorphology 102: 445-459.

McBride M, Hession WC, Rizzo DM. 2010. Riparian reforestation and channel change: How long does it take? Geomorphology 116: 330-340. 
McBride M, Hession WC, Rizzo DM, Thompson DM. 2007. The influence of riparian vegetation on near-bank turbulence: a flume experiment. Earth Surface Processes and Landforms 32: 2019-2037.

McKenney R, Jacobson RB, Wertheimer RC. 1995. Woody vegetation and channel morphogenesis in low-gradient, gravel-bed streams in the Ozark Plateaus, Missouri and Arkansas. Geomorphology 13: 175-198.

Menges ES. 1986. Environmental Correlates of Herb Species Composition in Five Southern Wisconsin Floodplain Forests. American Midland Naturalist 115: 106-117.

Merritt DM, Cooper DJ. 2000. Riparian vegetation and channel change in response to river regulation: a comparative study of regulated and unregulated streams in the Green River Basin, USA. Regulated Rivers: Research and Management 16: 543-564.

Merritt DM, Scott ML, Poff NL, Auble GT, Lytle DA. 2010. Theory, methods and tools for determining environmental flows for riparian vegetation: riparian vegetation-flow response guilds. Freshwater Biology 55: 206-225.

Micheli ER, Kirchner JW, Larsen EW. 2004. Quantifying the effect of riparian forest versus agricultural vegetation on river meander migration rates, central Sacramento River, California, USA. River Research and Applications 20: 537-548.

Millar RG. 2000. Influence of bank vegetation on alluvial channel patterns Water Resources Research 36: 1109-1118.

Millar RG. 2005. Theoretical regime equations for mobile gravel-bed rivers with stable banks. Geomorphology 64: 207-220.

Montgomery DR, Abbe TB. 2006. Influence of logjam-formed hard points on the formation of valley-bottom landforms in an old-growth forest valley, Queets River, Washington, USA. Quaternary Research 65: 147-155.

Mouw JEB, Chaffin JL, Whited DC, Hauer FR, Matson PL, Stanford JA. In press. Recruitment and successional dynamics diversify the shifting habitat mosaic of an Alaskan floodplain. River Research and Applications.

Mouw JEB, Stanford JA, Alaback PB. 2009. Influences of flooding and hyporheic exchange on floodplain plant richness and productivity. River Research and Applications 25: 929945.

Murgatroyd AL, Ternan JL. 1983. The impact of afforestation on stream bank erosion and channel form. Earth Surface Processes and Landforms 8: 357-369.

Murray AB, Paola C. 2003. Modelling the effect of vegetation on channel pattern in bedload rivers. Earth Surface Processes and Landforms 28: 131-143.

Murray AB, Knaapen MAF, Tal M, Kirwan ML. 2008. Biomorphodynamics: Physical-biological feedbacks that shape landscapes. Water Resources Research 44: W11301.

Naiman RJ, Décamps H. 1997. The Ecology of Interfaces: Riparian Zones. Annual Review of Ecology and Systematics 28: 621-658.

Nakamura F, Swanson FJ, Wondzell SM. 2000. Disturbance regimes of stream and riparian systems - a disturbance-cascade perspective. Hydrological Processes 14: 2849-2860.

Nanson GC. 1981. New evidence of scroll-bar formation on the Beatton River Sedimentology 28: 889-891.

Nanson GC, Beach HF. 1977. Forest Succession and Sedimentation on a Meandering-River Floodplain, Northeast British Columbia, Canada. Journal of Biogeography 4: 229-251.

Nanson GC, Knighton AD. 1996. Anabranching rivers: their causes, character and classification. Earth Surface Processes and Landforms 21: 217-239.

Nanson RA, Nanson GC, Huang HQ. 2010. The hydraulic geometry of narrow and deep channels; evidence for flow optimisation and controlled peatland growth. Geomorphology 117: 143-154.

Naumburg E, Mata-Gonzalez R, Hunter RG, McLendon T, Martin DW. 2005. Phreatophytic Vegetation and Groundwater Fluctuations: A Review of Current Research and Application of Ecosystem Response Modeling with an Emphasis on Great Basin Vegetation. Environmental Management 35: 726-740.

Neary VS, Constantinescu SG, Bennett SJ, Diplas P. 2011. Effects of Vegetation on Turbulence, Sediment Transport, and Stream Morphology. Journal of Hydraulic Engineering 138: 765-776.

Nilsson C, Svedmark M. 2002. Basic Principles and Ecological Consequences of Changing Water Regimes: Riparian Plant Communities. Environmental Management 30: 468480. 
Nygren P, Lu M, Ozier-Lafontaine H. 2009. Effects of turnover and internal variability of tree root systems on modelling coarse root architecture: comparing simulations for young Populus deltoides with field data. Canadian Journal of Forest Research-Revue Canadienne De Recherche Forestiere 39: 97-108.

O'Connor JE, Jones MA, Haluska TL. 2003. Flood plain and channel dynamics of the Quinault and Queets Rivers, Washington, USA. Geomorphology 51: 31-59.

O'Hare JM, O'Hare MT, Gurnell AM, Dunbar MJ, Scarlett PD, Laize C. 2010. Physical constraints on the distribution of macrophytes linked with flow and sediment dynamics in British rivers. River Research and Applications 27: 671-683.

Ollero A. 2007. Channel Adjustments, Floodplain Changes and Riparian Ecosystems of the Middle Ebro River: Assessment and Management. International Journal of Water Resources Development 23: 73 - 90.

Osterkamp WR. 1998. Processes of fluvial island formation, with examples from Plum Creek, Colorado and Snake River, Idaho. Wetlands 18: 530-545.

Osterkamp WR, Hupp CR. 1984. Geomorphic and vegetative characteristics along three northern Virginia streams. Geological Society of America Bulletin 95: 1093-1101.

Osterkamp WR, Hupp CR. 2010. Fluvial processes and vegetation -- Glimpses of the past, the present, and perhaps the future. Geomorphology 116: 274-285.

Osterkamp WR, Hupp CR, Stoffel M. 2012. The interactions between vegetation and erosion: new directions for research at the interface of ecology and geomorphology. Earth Surface Processes and Landforms 37: 23-36.

Page K, Nanson G. 1982. Concave-bank benches and associated floodplian formation. Earth Surface Processes and Landforms 7: 529-543.

Parker G, Shimizu Y, Wilkerson GV, Eke EC, Abad JD, Lauer JW, Paola C, Dietrich WE, Voller VR. 2010. A new framework for modeling the migration of meandering rivers. Earth Surface Processes and Landforms 36: 70-86.

Pasquale N, Perona P, Francis R, Burlando P. 2012. Effects of streamflow variability on the vertical root density distribution of willow cutting experiments. Ecological Engineering 40: 167-172.

Pautou G, Décamps H. 1985. Ecological interactions between the alluvial forests and hydrology of the Upper Rhone. Archiv fur Hydrobiologie 104: 13-37.

Pautou G, Décamps H, Amoros C, Bravard J-P. 1985. Successions vegetales dans les couloirs fluviaux: l'exemple de la plaine alluviale du Haut-Rhone francais. Bulletin d'Ecologie 16: 203-212.

Perona P, Molnar P, Crouzy B, Perucca E, Jiang Z, Mclelland S, Wuthrich D, Edmaier K, Francis R, Camporeale C, Gurnell A. 2012. Biomass selection by floods and related timescales: Part 1. Experimental observations. Advances in Water Resources 39: 8596.

Perucca E, Camporeale C, Ridolfi L. 2006. Influence of river meandering dynamics on riparian vegetation pattern formation. Journal of Geophysical Research 111: G01001

Perucca E, Camporeale C, Ridolfi L. 2007. Significance of the riparian vegetation dynamics on meandering river morphodynamics. Water Resources Research 43: W03430.

Pettit NE, Froend RH, Davies PM. 2001. Identifying the natural flow regime and the relationship with riparian vegetation for two contrasting western Australian rivers. Regulated Rivers-Research and Management 17: 201-215.

Pettit NE, Latterell JJ, Naiman RJ. 2006. Formation, distribution and ecological consequences of flood-related wood debris piles in a bedrock confined river in semi-arid South Africa. River Research and Applications 22: 1097-1110.

Pettit NE, Naiman RJ. 2006. Flood-deposited wood creates regeneration niches for riparian vegetation on a semi-arid South African river. Journal of Vegetation Science 17: 615624.

Piégay H. 1997. Interactions between Floodplain Forests and Overbank Flows: Data from Three Piedmont Rivers of Southeastern France. Global Ecology and Biogeography Letters 6: 187-196.

Pietsch TJ, Nanson GC. 2011. Bankfull hydraulic geometry; the role of in-channel vegetation and downstream declining discharges in the anabranching and distributary channels of the Gwydir distributive fluvial system, southeastern Australia. Geomorphology 129: 152165.

Pizzuto J, O'Neal M, Stotts S. 2010. On the retreat of forested, cohesive riverbanks. Geomorphology 116: 341-352. 
Pollen N, Simon A. 2005. Estimating the mechanical effects of riparian vegetation on stream bank stability using a fiber bundle model. Water Resources Research 41: W07025.

Pollen-Bankhead N, Simon A. 2009. Enhanced application of root-reinforcement algorithms for bank-stability modeling Earth Surface Processes and Landforms 34: 471-480.

Pollen-Bankhead N, Simon A. 2010. Hydrologic and hydraulic effects of riparian root networks on streambank stability: Is mechanical root-reinforcement the whole story? Geomorphology 116: 353-362.

Pollen-Bankhead N, Simon A, Jaeger K, Wohl, E. 2009. Destabilization of streambanks by removal of invasive species in Canyon de Chelly National Monument, Arizona. Geomorphology 103: 363-374.

Pollen-Bankhead N, Thomas RE, Gurnell AM, Liffen T, Simon A, O'Hare MT. 2011. Quantifying the potential for flow to remove the emergent aquatic macrophyte Sparganium erectum from the margins of low-energy rivers. Ecological Engineering 37: 1779-1788.

Predick KI, Gergel SE, Turner MG. 2009. Effect of flood regime on tree growth in the floodplain and surrounding uplands of the Wisconsin River. River Research and Applications 25: 283-296.

Pringle CM, Naiman RJ, Bretschko G, Karr JR, Oswood MW, Jackson RW, Welcomme RL, Winterbourn MJ. 1988. Patch Dynamics in Lotic Systems: The Stream as a Mosaic. Journal of the North American Benthological Society 7: 503-524.

Puhakka M, Kalliola R, Rajasilta M, Salo J. 1992. River types, site evolution and successional vegetation patterns in Peruvian Amazonia. Journal of Biogeography 19: 651-665.

Rhoads BL, Massey KD. 2012. Flow structure and channel change in a sinuous grass-lined stream within an agricultural drainage ditch: Implications for ditch stability and aquatic habitat. River Research and Applications 28: 39-52.

Richter BD, Richter H. 2000. Prescribing flood regimes to sustain riparian ecosystems along meandering rivers. Conservation Biology 14: 1468-1478.

Rietkerk M, Dekker SC, De Ruiter PC, Van De Koppel J. 2004. Self-Organized Patchiness and Catastrophic Shifts in Ecosystems. Science 305: 1926-1929.

Riis T, Biggs BJF. 2003. Hydrologic and hydraulic control of macrophyte establishment and performance in streams. Limnology and Oceanography 48: 1488-1497.

Riis T, Sand-Jensen KAJ. 2006. Dispersal of plant fragments in small streams. Freshwater Biology 51: 274-286.

Riis T, Sand-Jensen K, Vestergaard O. 2000. Plant communities in lowland Danish streams: species composition and environmental factors. Aquatic Botany 66: 255-272.

Riis T, Sand-Jensen K, Larsen SE. 2001. Plant distribution and abundance in relation to physical conditions and location within Danish stream systems. Hydrobiologia 448: 217228.

Robach F, Eglin I, Tremolieres M. 1997. Species Richness of Aquatic Macrophytes in Former Channels Connected to a River: A Comparison between Two Fluvial Hydrosystems Differing in Their Regime and Regulation. Global Ecology and Biogeography Letters 6: 267-274.

Robertson KM. 2006. Distributions of tree species along point bars of 10 rivers in the southeastern US Coastal Plain. Journal of Biogeography 33: 121-132.

Robertson KM, Augspurger CK. 1999. Geomorphic processes and spatial patterns of primary forest succession on the Bogue Chitto River, USA. Journal of Ecology 87: 1052-1063.

Rood SB, Goater LA, Gill KM, Braatne JH. 2011. Sand and sandbar willow: a feedback loop amplifies environmental sensitivity at the riparian interface. Oecologia 165: 31-40.

Rood SB, Gourley CR, Ammon EM, Heki LG, Klotz JR, Morrison ML, Mosley D, Scoppettone GG, Swanson S, Wagner PL. 2003a. Flows for Floodplain Forests: A Successful Riparian Restoration. BioScience 53: 647-656.

Rood SB, Kalischuk AR, Polzin ML, Braatne JH. 2003b. Branch propagation, not cladoptosis, permits dispersive, clonal reproduction of riparian cottonwoods. Forest Ecology and Management 186: 227-242.

Rood SB, Mahoney JM. 1995. River damming and riparian cottonwoods along the Marias River, Montana. Rivers 5: 195-207.

Rood SB, Samuelson GM, Braatne JH, Gourley CR, Hughes FMR, Mahoney JM. 2005. Managing river flows to restore floodplain forests. Frontiers in Ecology and the Environment 3: 193-201. 
Rowntree K. 1991. An assessment of the potential impact of alien invasive vegetation on the geomorphology of river channels in South Africa. South African Journal of Aquatic Science 17: 28-43.

Rutherfurd ID, Grove JR. 2004. The influence of trees on stream bank erosion: Evidence from root-plate abutments. In: Riparian Vegetation and Fluvial Geomorphology. Bennett SJ, Simon A (eds). Water Science and Application. Amer Geophysical Union, Washington, 141-152.

Salo J, Kalliola R, Hakkinen I, Makinen Y, Niemela P, Puhakka M, Coley PD. 1986. River dynamics and the diversity of Amazon lowland forest. Nature 322: 254-258.

Sand-Jensen K. 1998. Influence of submerged macrophytes on sediment composition and near-bed flow in lowland streams. Freshwater Biology 39: 663-679.

Sand-Jensen K. 2008. Drag forces on common plant species in temperate streams: consequences of morphology, velocity and biomass. Hydrobiologia 610: 307-319.

Sand-Jensen K, Pedersen O. 1999. Velocity gradients and turbulence around macrophyte stands in streams. Freshwater Biology 42: 315-328.

Sand-Jensen KAJ, Pedersen ML. 2008. Streamlining of plant patches in streams. Freshwater Biology 53: 714-726.

Schoelynck J, De Groote T, Bal K, Vandenbruwaene W, Meire P, Temmerman S. 2012. Selforganised patchiness and scale-dependent bio-geomorphic feedbacks in aquatic river vegetation. Ecography 35: 760-768.

Schutten J, Dainty J, Davy AJ. 2005. Root anchorage and its significance for submerged plants in shallow lakes. Journal of Ecology 93: 556-571.

Schutten J, Davy AJ. 2000. Predicting the hydraulic forces on submerged macrophytes from current velocity, biomass and morphology. Oecologia 123: 445-452.

Schulz M, Kozerski HP, Pluntke T, Rinke K. 2003. The influence of macrophytes on sedimentation and nutrient retention in the lower River Spree (Germany). Water Research 37: 569-578.

Scippa GS, Trupiano D, Rocco M, Di lorio A, Chiatante D. 2008. Unravelling the response of poplar (Populus nigra) roots to mechanical stress imposed by bending. Plant Biosystems 142: 401-413.

Scott ML, Friedman JM, Auble GT. 1996. Fluvial process and the establishment of bottomland trees. Geomorphology 14: 327-339.

Sear DA, Millington CE, Kitts DR, Jeffries R. 2010. Logjam controls on channel:floodplain interactions in wooded catchments and their role in the formation of multi-channel patterns. Geomorphology 116: 305-319.

Shafroth PB, Friedman JM, Auble GT, Scott ML, Braatne JH. 2002. Potential responses of riparian vegetation to dam removal. BioScience 52: 703-712.

Sharpe RG, James CS. 2006. Deposition of sediment from suspension in emergent vegetation. Water South Africa 32: 211-218.

Sharp JL, Sojda RS, Greenwood M, Rosenberry DO, Warren JM. In press. Statistical classification of vegetation and water depths in montane wetlands. Ecohydrology.

Shields FD, Gray DH., 1992. Effects of woody vegetation on sandy levee integrity. Water Resources Bulletin 28: 917-931.

Simon A, Collison AJC. 2002. Quantifying the mechanical and hydrologic effects of riparian vegetation on streambank stability. Earth Surface Processes and Landforms 27: 527546.

Simon A, Hupp CR. 1990. The recovery of alluvial systems in response to imposed channel modifications, West Tennessee, USA. In: Vegetation and Erosion: Processes and Environments. Thornes JB (ed). Wiley, Chichester, 145-160.

Singer MB, Stella JC, Dufour S, Piégay H, Wilson RJS, Johnstone L. in press. Contrasting water-uptake and growth responses to drought in co-occurring riparian tree species. Ecohydrology.

Smith DG. 1976. Effect of vegetation on lateral migration of anastomosed channels of a glacial meltwater river. Geological Society of America Bulletin 87: 857-860.

Smith JD. 2004. The role of riparian shrubs in preventing floodplain unravelling along the Clark Fork of the Columbia River in Deer Lodge Valley, Montana. In: Riparian Vegetation and Fluvial Geomorphology, Bennett SJ, Simon A (eds).. Water Science and Application. American Geophysical Union, Washington, D.C., 71-85. 
Stallins JA, Nesius M, Smith M, Watson K. 2010. Biogeomorphic characterization of floodplain forest change in response to reduced flows along the Apalachicola River, Florida. River Research and Applications 26: 242-260.

Stanford JA, Lorang MS, Hauer FR. 2005. The shifting habitat mosaic of river ecosystems. Verh. Internat. Verein. Limnol 29: 123-136.

Steiger J, Tabacchi E, Dufour S, Corenblit D, Peiry JL. 2005. Hydrogeomorphic processes affecting riparian habitat within alluvial channel-floodplain river systems: a review for the temperate zone. River Research and Applications 21: 719-737.

Stoffel M, Wilford DJ. 2012. Hydrogeomorphic processes and vegetation: disturbance, process histories, dependencies and interactions. Earth Surface Processes and Landforms 37: 9-22.

Stone MC, Chen L, Kyle Mckay S, Goreham J, Acharya K, Fischenich C, Stone AB. 2013. Bending of submerged woody riparian vegetation as a function of hydraulic flow conditions. River Research and Applications, 29, 195-205.

Stromberg JC. 2001. Restoration of riparian vegetation in the south-western United States: importance of flow regimes and fluvial dynamism. Journal of Arid Environments 49: 1734.

Stromberg JC, Beauchamp VB, Dixon MD, Lite SJ, Paradzick C. 2007. Importance of low-flow and high-flow characteristics to restoration of riparian vegetation along rivers in and south-western United States. Freshwater Biology 52: 651-679.

Stromberg JC, Lite SJ, Dixon MD. 2010. Effects of stream flow patterns on riparian vegetation of a semiarid river: Implications for a changing climate. River Research and Applications 26: 712-729.

Stromberg JC, Patten DT. 1996. Instream flow and cottonwood growth in the eastern Sierra Nevada of California, USA. Regulated Rivers: Research and Management 12: 1-12.

Swanson FJ, Johnson SL, Gregory SV, Acker SA. 1998. Flood Disturbance in a Forested Mountain Landscape: Interactions of land use and floods. BioScience 48:681-689.

Sweeney BW, Bott TL, Jackson JK, Kaplan LA, Newbold JD, Standley LJ, Hession WC, Horwitz RJ. 2004.Riparian deforestation, stream narrowing, and loss of stream ecosystem services. Proceedings of the National Academy of Sciences of the United States of America 101:14132-14137.

Tabacchi E, Steiger J, Corenblit D, Monaghan MT, Planty-Tabacchi AM. 2009.Implications of biological and physical diversity for resilience and resistance patterns within Highly Dynamic River Systems. Aquatic Sciences 71:279-289.

Tal M, Paola C. 2007. Dynamic single-thread channels maintained by the interaction of flow and vegetation. Geology 35: 347-350.

Tal M, Paola C. 2010. Effects of vegetation on channel morphodynamics: results and insights from laboratory experiments. Earth Surface Processes and Landforms 35: 1014-1028.

Tal M, Gran K, Murray AD, Paola C, Hicks DM. 2004. Riparian vegetation as a primary control on channel characteristics in multi-thread rivers. In: Riparian Vegetation and Fluvial Geomorphology. Bennett SJ, Simon A (eds). Water Science and Application, Vol. 8. American Geophysical Union, Washington, D.C., 43-58.

Tanaka N, Yagisawa J. 2009. Effects of tree characteristics and substrate condition on critical breaking moment of trees due to heavy flooding. Landscape and Ecological Engineering 5: 59-70.

Tealdi S, Camporeale C, Perucca E, Ridolfi L. 2010. Longitudinal dispersion in vegetated rivers with stochastic flows. Advances in Water Resources 33: 562-571.

Thorne CR. 1990. Effects of vegetation on riverbank erosion and stability In: Vegetation and Erosion: Processes and Environments. Thornes JB (ed). Wiley, Chichester, 125-144.

Thornes JB. (ed.) 1990. Vegetation and Erosion: Processes and Environments. Wiley, Chichester, 518pp..

Toledo ZO, Kauffman JB. 2001. Root biomass in relation to channel morphology of headwater streams. Journal of the American Water Resources Association 37: 1653-1663.

Tooth S. 2000. Downstream changes in dryland river channels: the Northern Plains of arid central Australia. Geomorphology 34: 33-54.

Tooth S, Jansen JD, Nanson GC, Coulthard TJ, Pietsch T. 2007. Riparian vegetation and the late Holocene development of an anabranching river: Magela Creek, northern Australia. Bulletin of the Geological Society of America 119: 452-461. 
Tooth S, McCarthy TS. 2004a. Anabranching in mixed bedrock-alluvial rivers: the example of the Orange River above Augrabies Falls, Northern Cape Province, South Africa. Geomorphology 57: 235-262.

Tooth S, McCarthy TS. 2004b. Controls on the transition from meandering to straight channels in the wetlands of the Okavango Delta, Botswana. Earth Surface Processes and Landforms 29: 1627-1649.

Tooth S, Nanson GC. 1999. Anabranching rivers on the Northern Plains of arid central Australia. Geomorphology 29: 211-233.

Tooth S, Nanson GC. 2000. The role of vegetation in the formation of anabranching channels in an ephemeral river, Northern plains, arid central Australia. Hydrological Processes 14: 3099-3117.

Trimble SW. 1997. Stream channel erosion and change resulting from riparian forests. Geology 25: 467-469.

Turner MG, Gergel SE, Dixon MD, Miller JR. 2004. Distribution and abundance of trees in floodplain forests of the Wisconsin River: Environmental influences at different scales. Journal of Vegetation Science 15: 729-738.

van Coller AL, Rogers KH, Heritage GL. 1997. Linking riparian vegetation types and fluvial geomorphology along the Sabie River within the Kruger National Park, South Africa. African Journal of Ecology 35: 194-212.

van Coller AL, Rogers KH, Heritage GL. 2000. Riparian vegetation-environment relationships: complimentarity of gradients versus patch hierarchy approaches. Journal of Vegetation Science 11: 337-350.

van de Wiel MJ, Darby SE. 2007. A new model to analyse the impact of woody riparian vegetation on the geotechnical stability of riverbanks. Earth Surface Processes and Landforms 32: 2185-2198.

Viles HA, Naylor LA, Carter NEA, Chaput D. 2008. Biogeomorphological disturbance regimes: progress in linking ecological and geomorphological systems. Earth Surface Processes and Landforms 33: 1419-1435.

Vincent KR, Friedman JM, Griffin ER. 2009. Erosional Consequence of Saltcedar Control. Enviironmental Management 44: 218-227.

Watters JR, Stanley EH. 2007. Stream channels in peatlands: The role of biological processes in controlling channel form. Geomorphology 89: 97-110.

Welber M, Bertoldi W, Tubino M. 2012. The response of braided planform configuration to flow variations, bed reworking and vegetation: the case of the Tagliamento River, Italy. Earth Surface Processes and Landforms 37: 572-582.

Wende R, Nanson GC. 1998. Anabranching rivers: ridge-form alluvial channels in tropical northern Australia. Geomorphology 22: 205-224.

Wynn TM, Mostaghimi S, Burger JA, Harpold AA, Henderson MB, Henry LA. 2004. Variation in root density along stream banks. Journal of Environmental Quality 33: 2030-2039.

Zierholz C, Prosser IP, Fogarty PJ, Rustomji P. 2001. In-stream wetlands and their significance for channel filling and the catchment sediment budget, Jugiong Creek, New South Wales. Geomorphology 38: 221-235.

Zimmerman RC, Goodlet JC, Comer GH. 1967. The influence of vegetation on channel form of small streams. In: Proceedings of the Symposium on River Morphology. International Association of Scientific Hydrology, Publication 75, 255-275

Zong L, Nepf H. 2010. Flow and deposition in and around a finite patch of vegetation. Geomorphology 116: 363-372. Abbe TB, Montgomery DR. 2003. Patterns and processes of wood debris accumulation in the Queets river basin, Washington. Geomorphology 51: 81-107. 
Figure Underlines
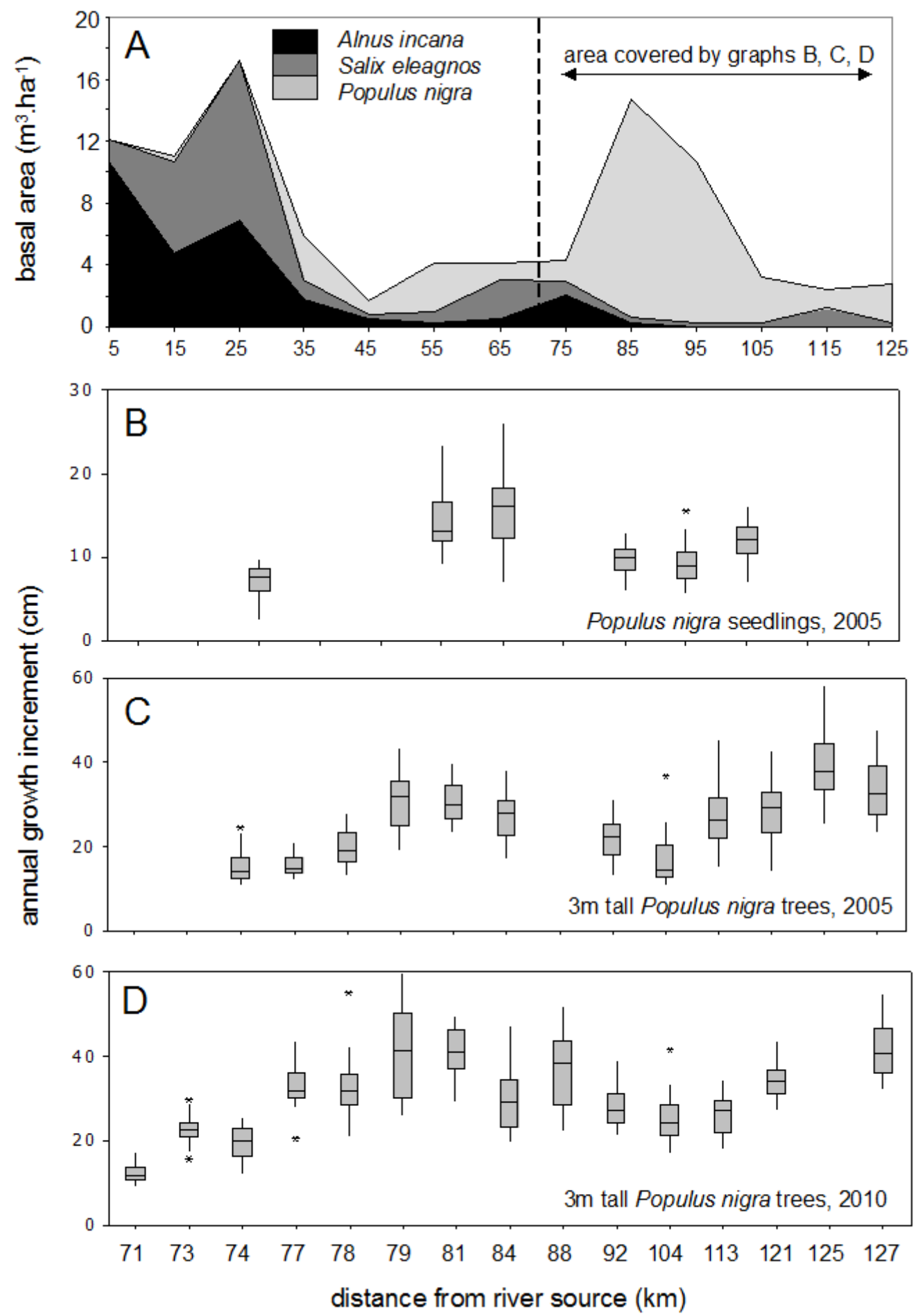

Figure 1

A. Changes in the basal area of three tree species on early-stage islands along the Tagliamento (data from Karrenberg et al., 2003a). B, C and D annual growth increments of $P$. nigra seedlings (B), and 3m tall shrubs (C and D) observed in 2005 $(\mathrm{B}, \mathrm{C})$ and 2010 (D) at various sites along the middle and lower reaches of the Tagliamento River, Italy. Note the difference in vertical axis scales between the seedling (B) and the $3 \mathrm{~m}$ tall shrub (C and D) graphs. 
PHYSICAL

VEGETATION

PROCESSES

PROPERTIES

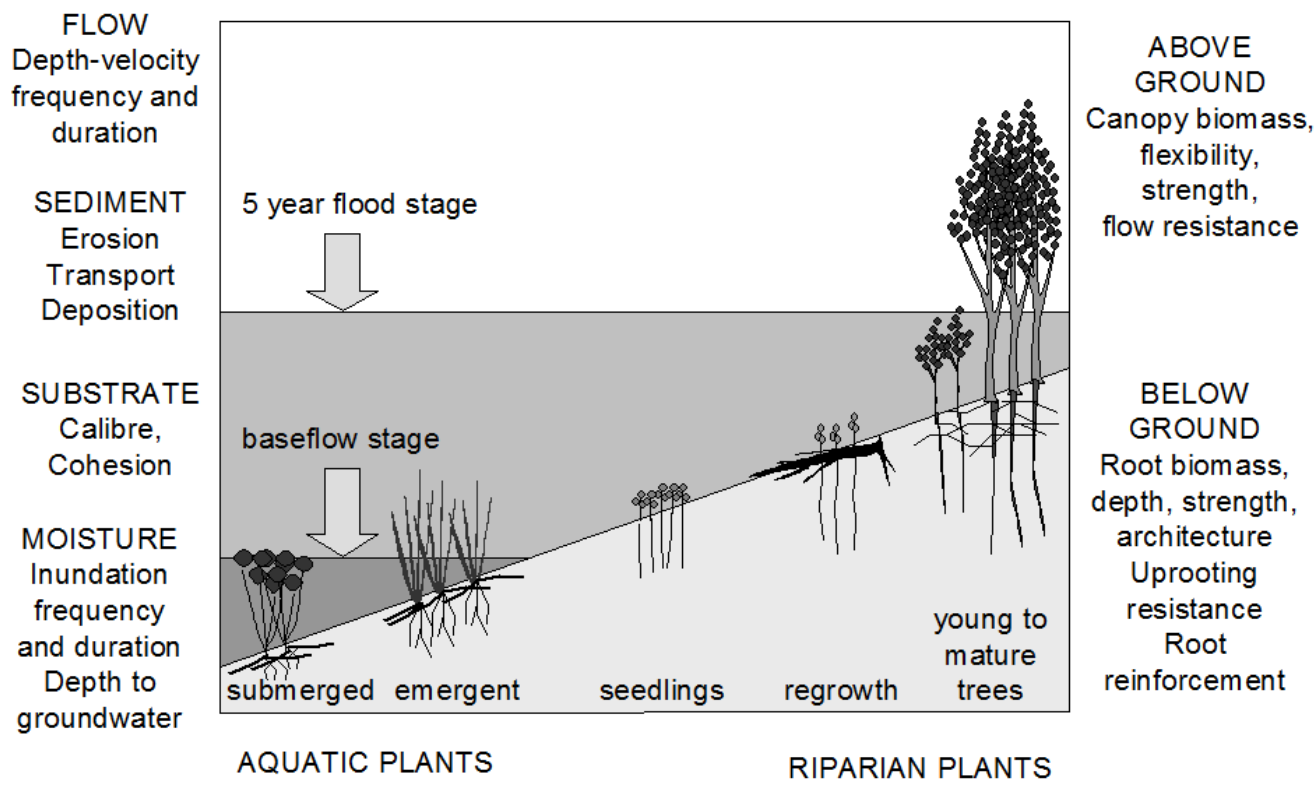

Figure 2

Physical processes that constrain riparian and aquatic plant colonisation and growth, and the biomechanical properties that enable plants of different species and growth stage to cope with the physical processes. The relative importance of the physical processes varies from the left to right of the diagram and also through time as river stage and discharge varies. 


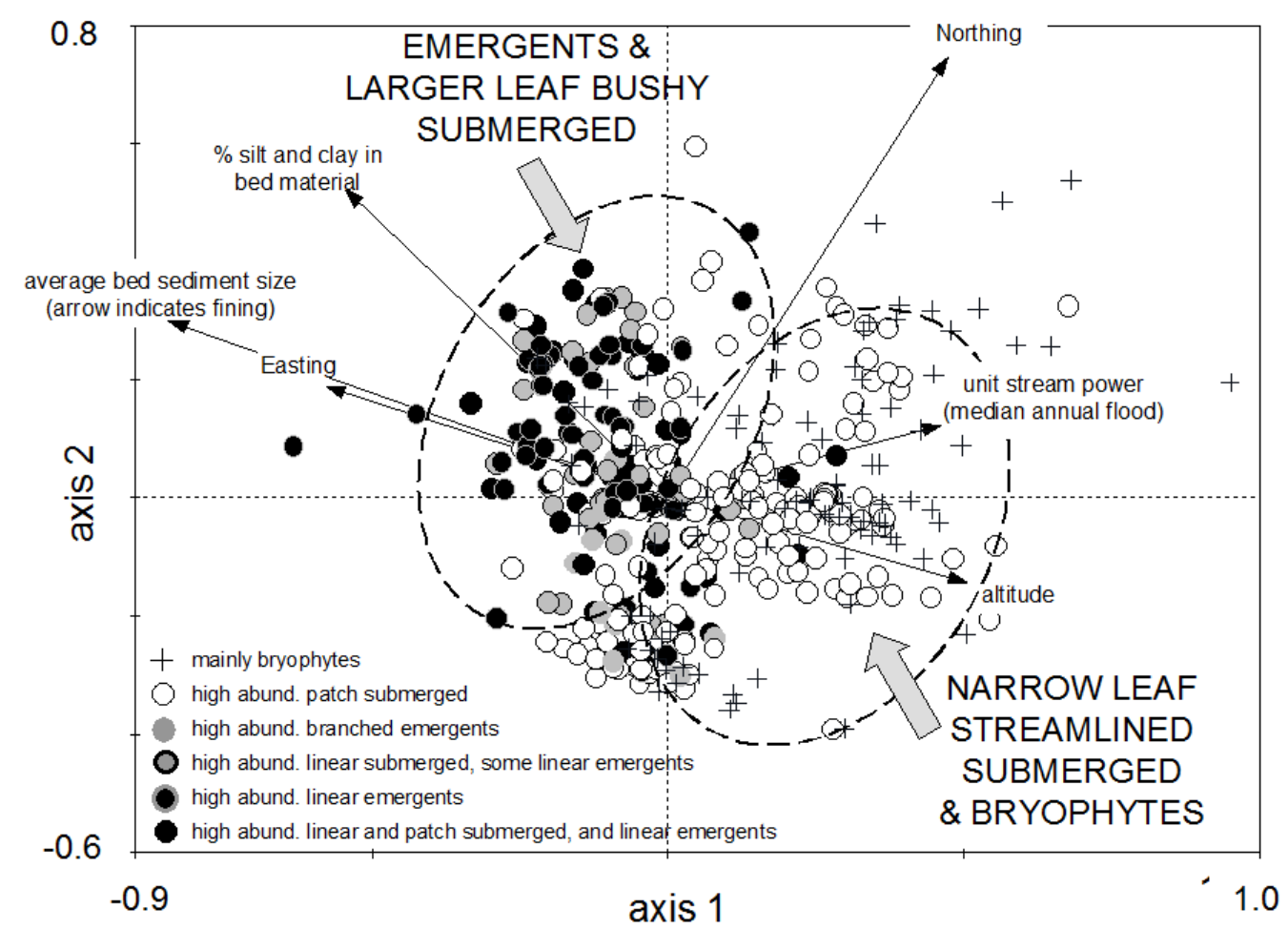

Figure 3

Distribution of aquatic plant morphotypes in British rivers, according to geographical position (Northing, Easting, altitude) and physical environment properties (unit stream power, average bed sediment size, percentage silt and clay in bed material), as revealed by a Canonical Correspondence Analysis of data from 467 river reaches. (for more information see Gurnell et al., 2010) 


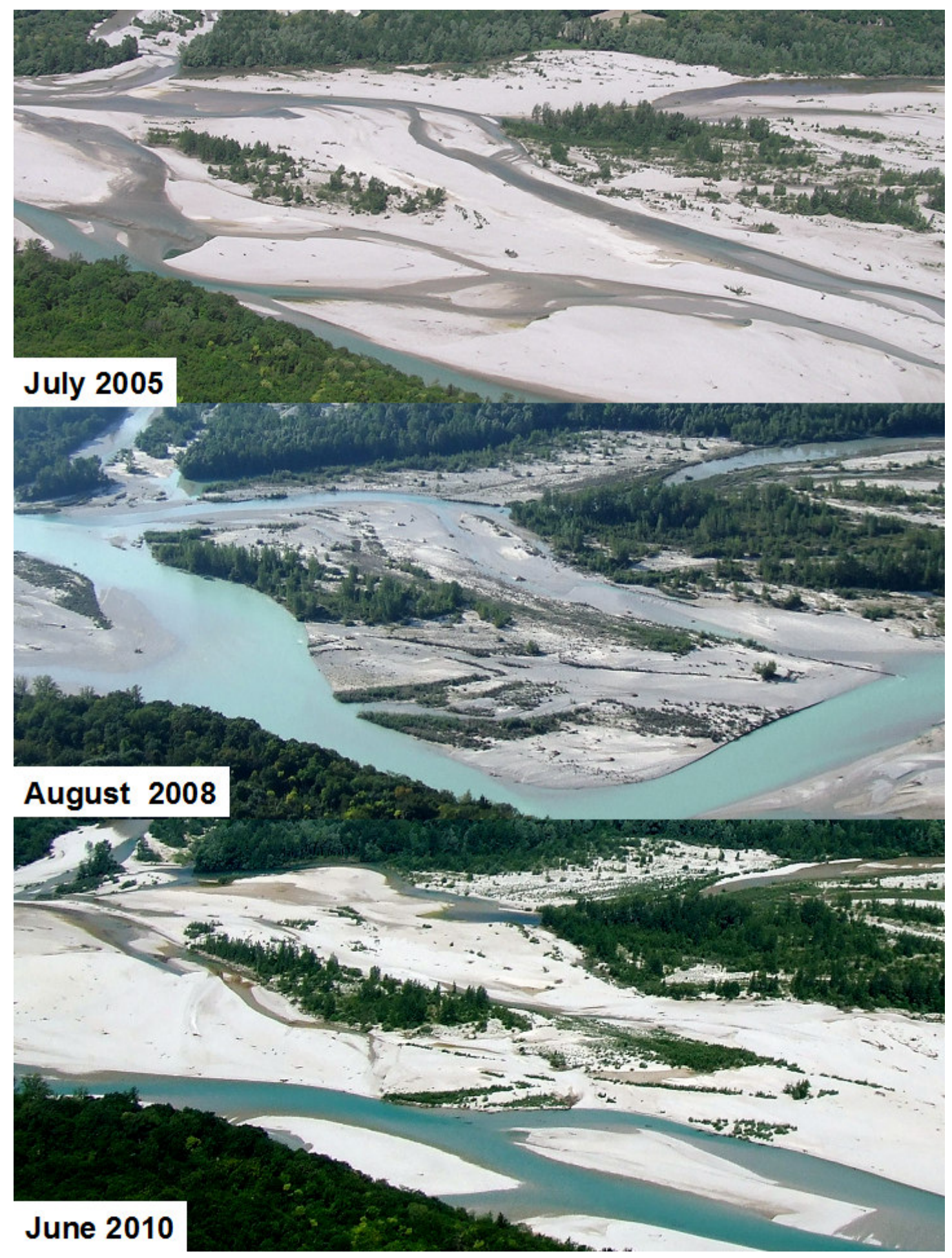

Figure 4. Shifting mosaic of open water, bare gravel, and vegetated patches of different ground cover, biomass, height and species composition at the same site on the Tagliamento River in July 2005 (following a bankfull flood in winter 2004-2005); in August 2008 (following three years without any significant floods); and June 2010, (following two years with some significant floods, although none reached bankfull stage).

(photographs by A. Gurnell) 

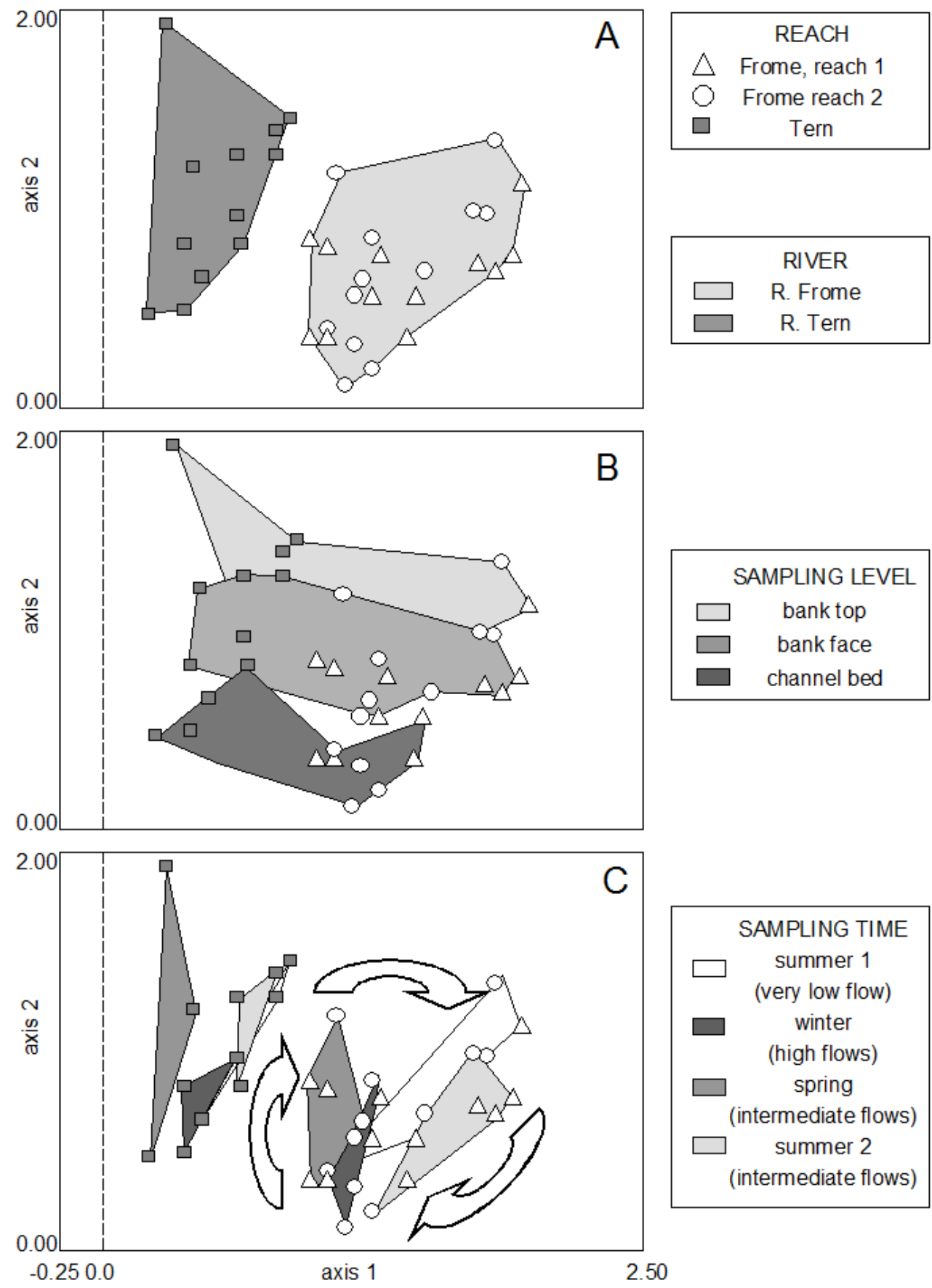

Figure 5. Variations in seed species composition found in sediments deposited on the banks and bed of two British rivers. The scatter plots show the plotting positions of sets (typically 9) of samples obtained from the bank top, bank face, and river bed during four 4-month time periods, along three reaches of two rivers in relation to the first two axes of a detrended correspondence analysis. The polygons highlight groups of samples to illustrate how species composition varies according to (A) the species pool available within the catchment; (B) the sampling position, particularly its elevation and thus the likely balance of seed delivery by water (indundation) and air (direct fall and wind blown), and (C) the time of year and flow levels of the sampling period. (for more information see Gurnell et al., 2008) 

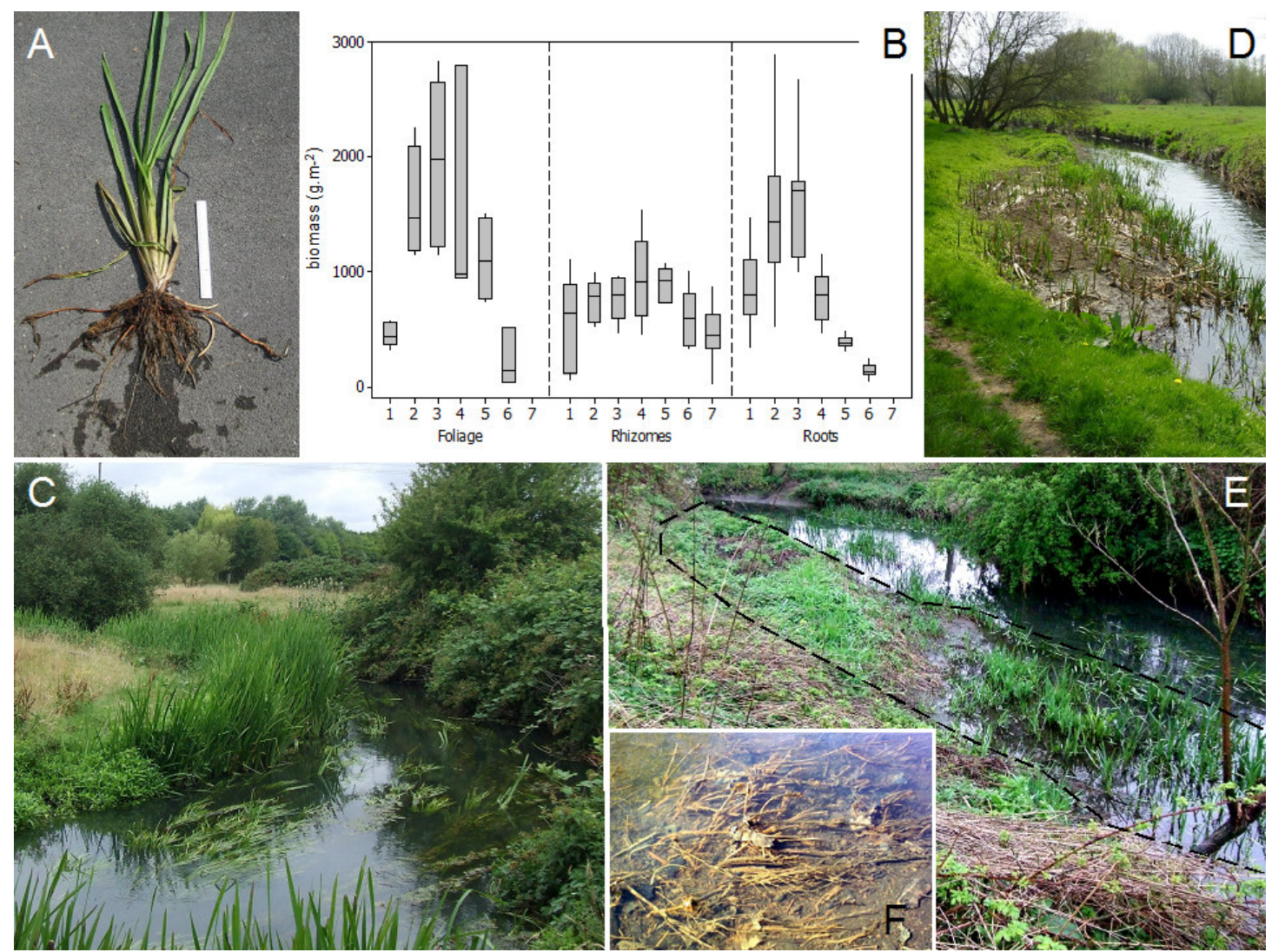

Figure 6. Structure, annual growth and landform-building by Sparganium erectum.

A. A plant uprooted in June, illustrating full shoot development and a substantial network of fine roots and thicker rhizomes.

B. annual cycle in the development of shoot, rhizome and root biomass $(1=23$ May, $2=30$ June, $3=5$ August, $4=3$ September, $5=8$ October, $6=23$ November, $7=14$ January).

C. a large stand of S. erectum growing on the inner bank of a river bend in July.

D.and E. bench development resulting from sediment trapping by S.erectum and subsequent aggradation around other colonising plants (photographs taken in late April)

F. rhizomes exposed by a winter flood.

(photographs A, C, E by A. Gurnell, D by W. Bertoldi, F by T. Liffen) 


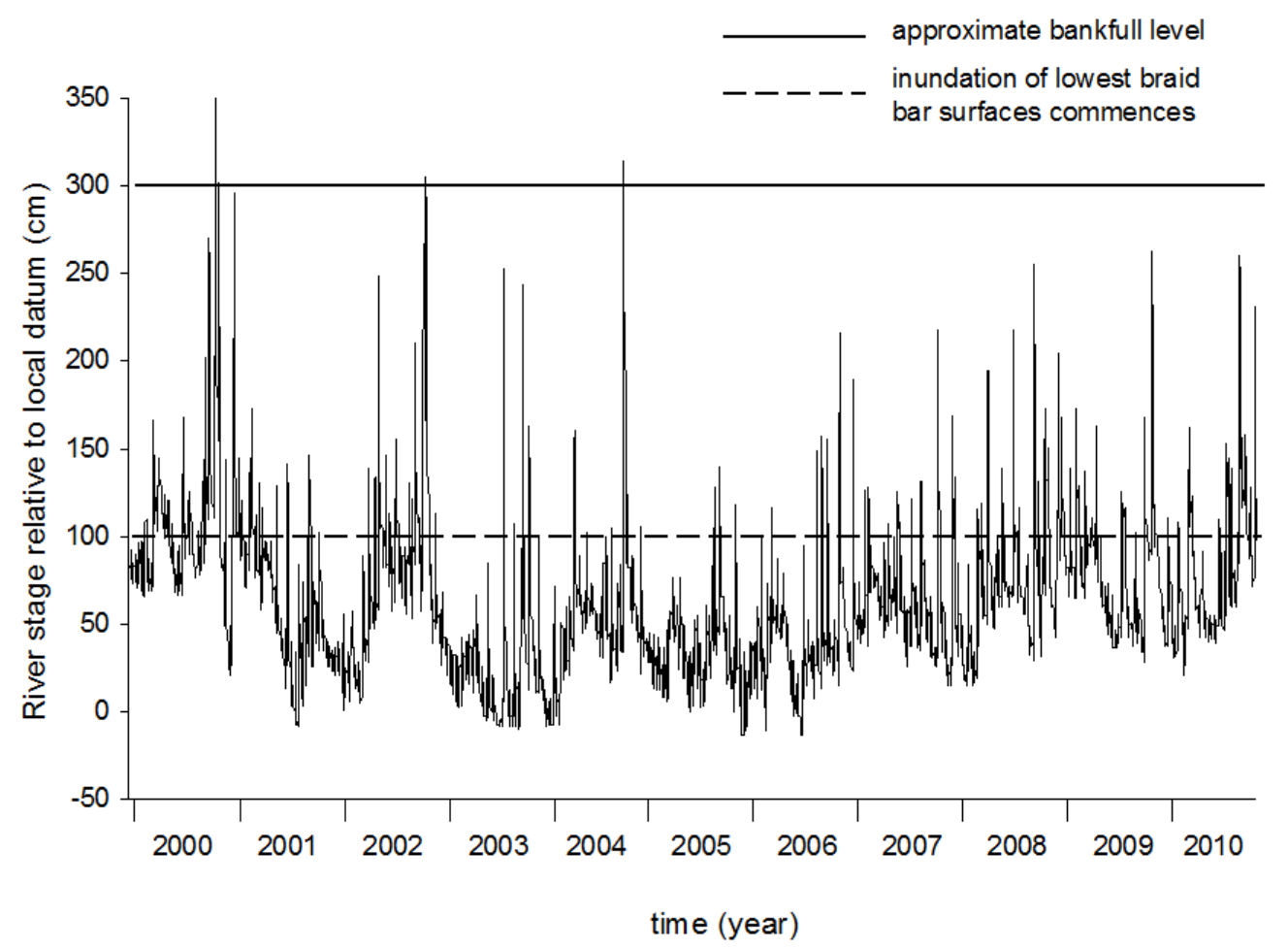

Figure 7. Variations in river stage at river kilometre 83 of the Tagliamento River, Italy, 1 January 2000 to 31 December 2010. The bankfull level and level at which the lowest bars start to be inundated is relevant to the reach immediately upstream of the gauge between river kilometres 74 and 83 . 


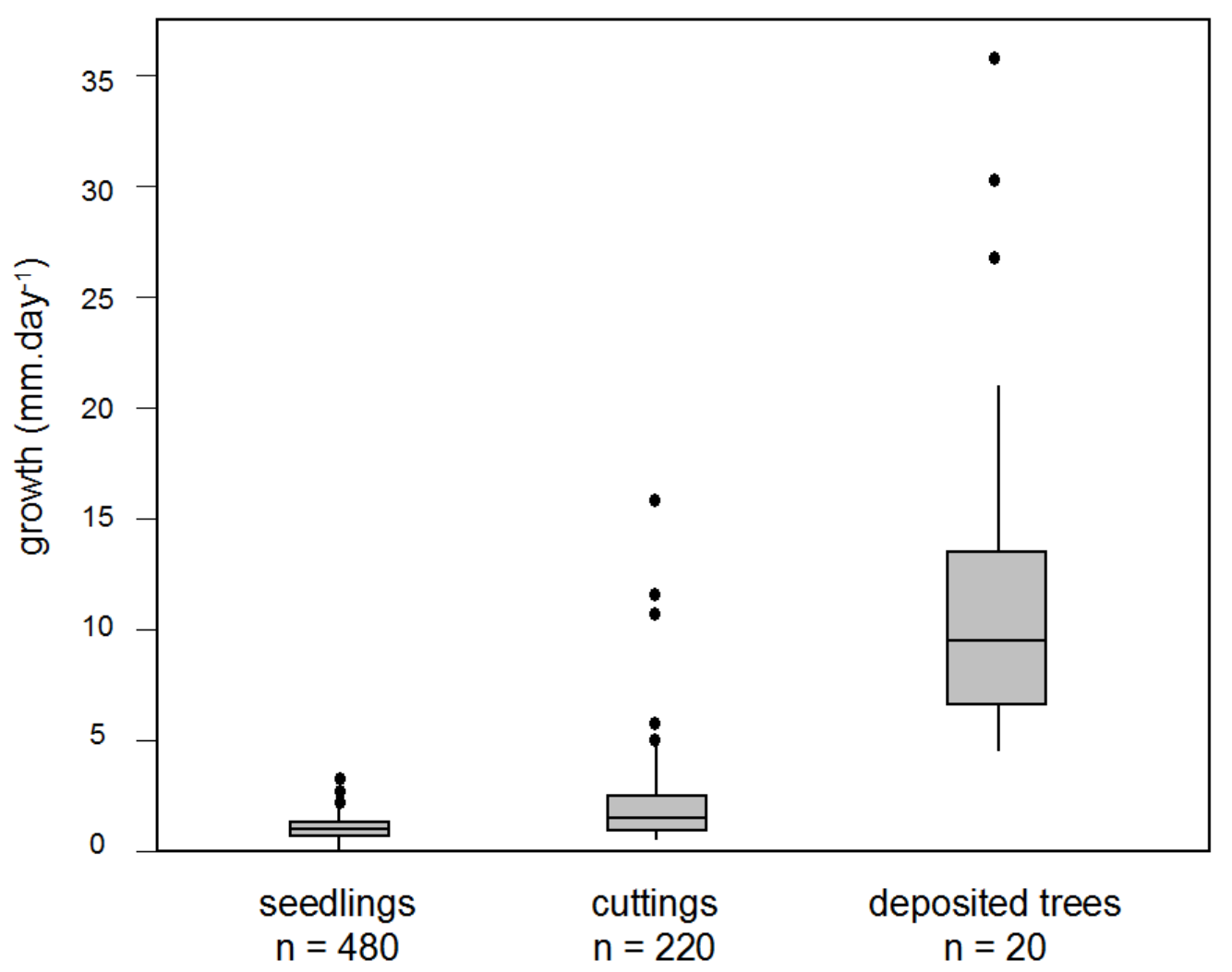

Figure 8 Average daily growth increments of propagules of $P$. nigra in the first growing season, estimated from the main shoot from seedlings and cuttings and the longest of 10 shoots spaced evenly along the trunk of uprooted trees. All sampled individuals were growing on open bar tops on surface sediments ranging from siltysand to coarse gravel at a site $79 \mathrm{~km}$ downstream from the source of the Tagliamento during the 2003 and 2004 growing seasons. 


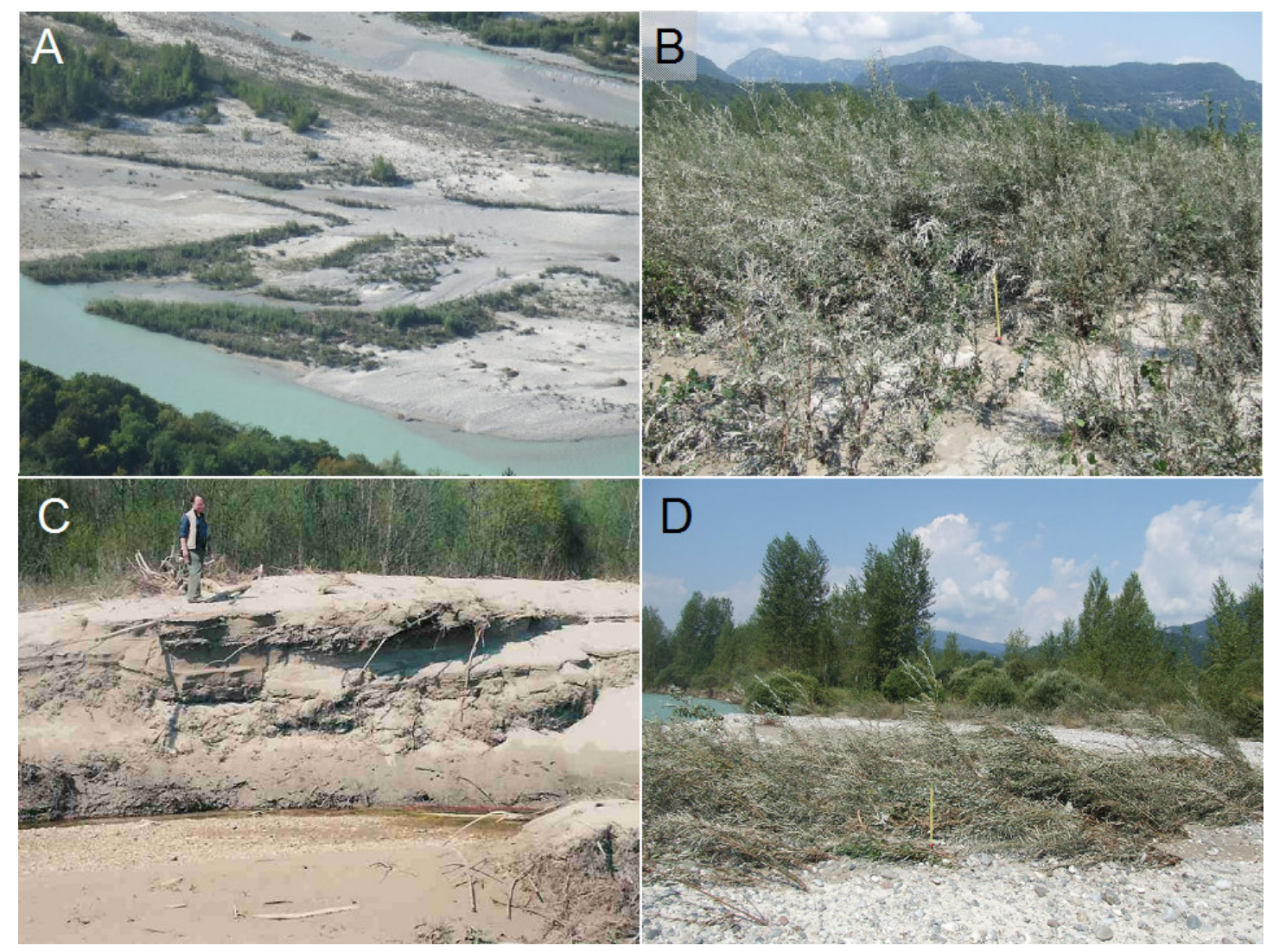

Figure 9 Tagliamento River, Italy.

A. strips of Salicaceae seedlings along the margins of low flow channels in August, B. and D. close up views of strips of Salix eleagnos seedlings in August immediately after a flood, showing minor canopy deformation and heavy deposition of fine sediment ( $\mathrm{B}$ - the marker is $0.5 \mathrm{~m}$ tall) and major canopy deformation and fine sediment scour ( $\mathrm{D}$ - the marker is $0.5 \mathrm{~m}$ tall)

C. Shoots (top) and living wood pieces (eroding face) within a scroll bar in mid April. (photographs by A. Gurnell) 


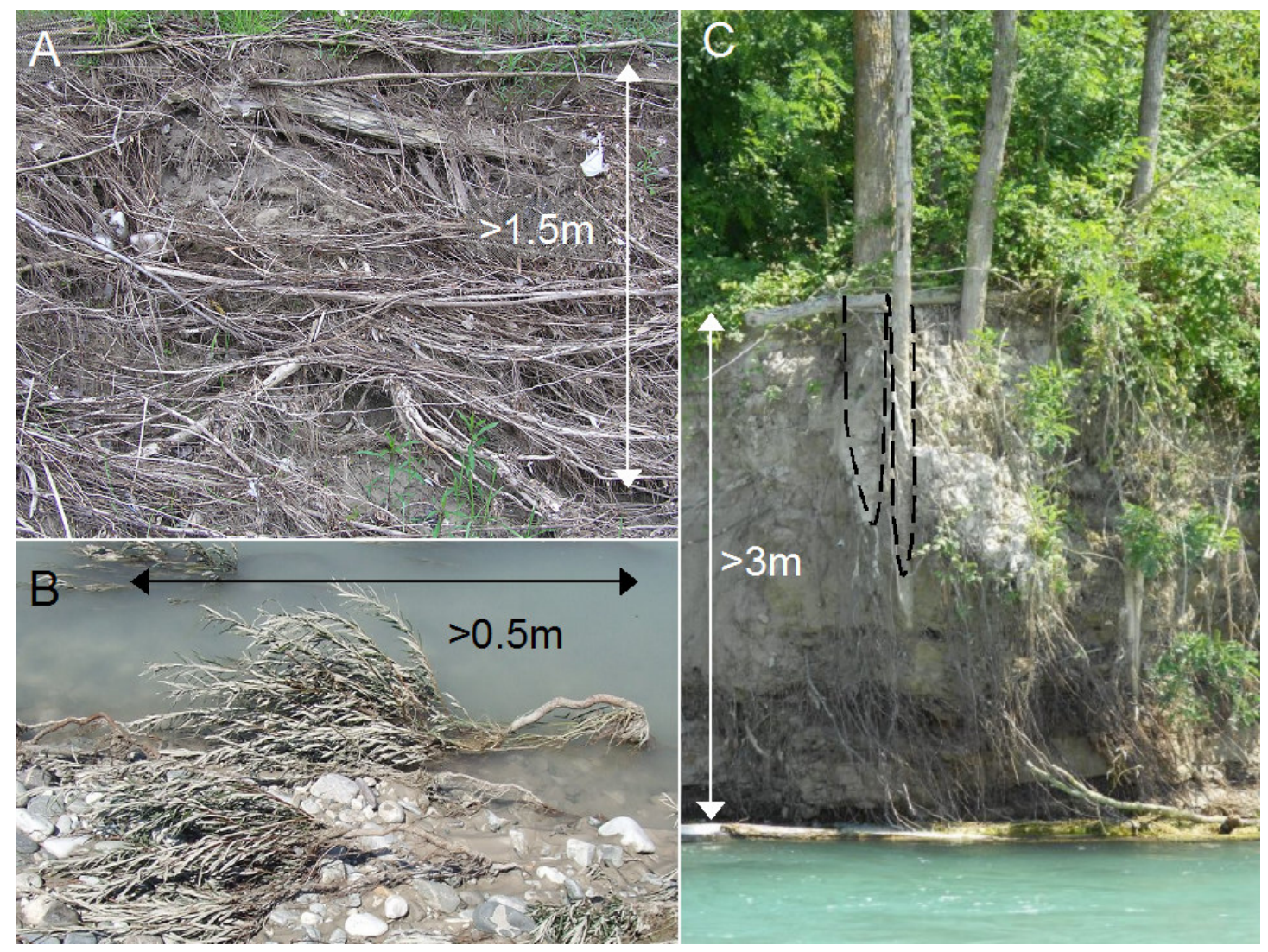

Figure 10 Tagliamento River, Italy

A. Exposure of a dense network of riparian tree roots on an eroding river bank

B. Salix eleagnos seedlings scoured to expose the upper part of their tap roots

C. Buried trunks and adventitious roots of Populus nigra exposed on an eroding river bank

(photographs by A. Gurnell). 

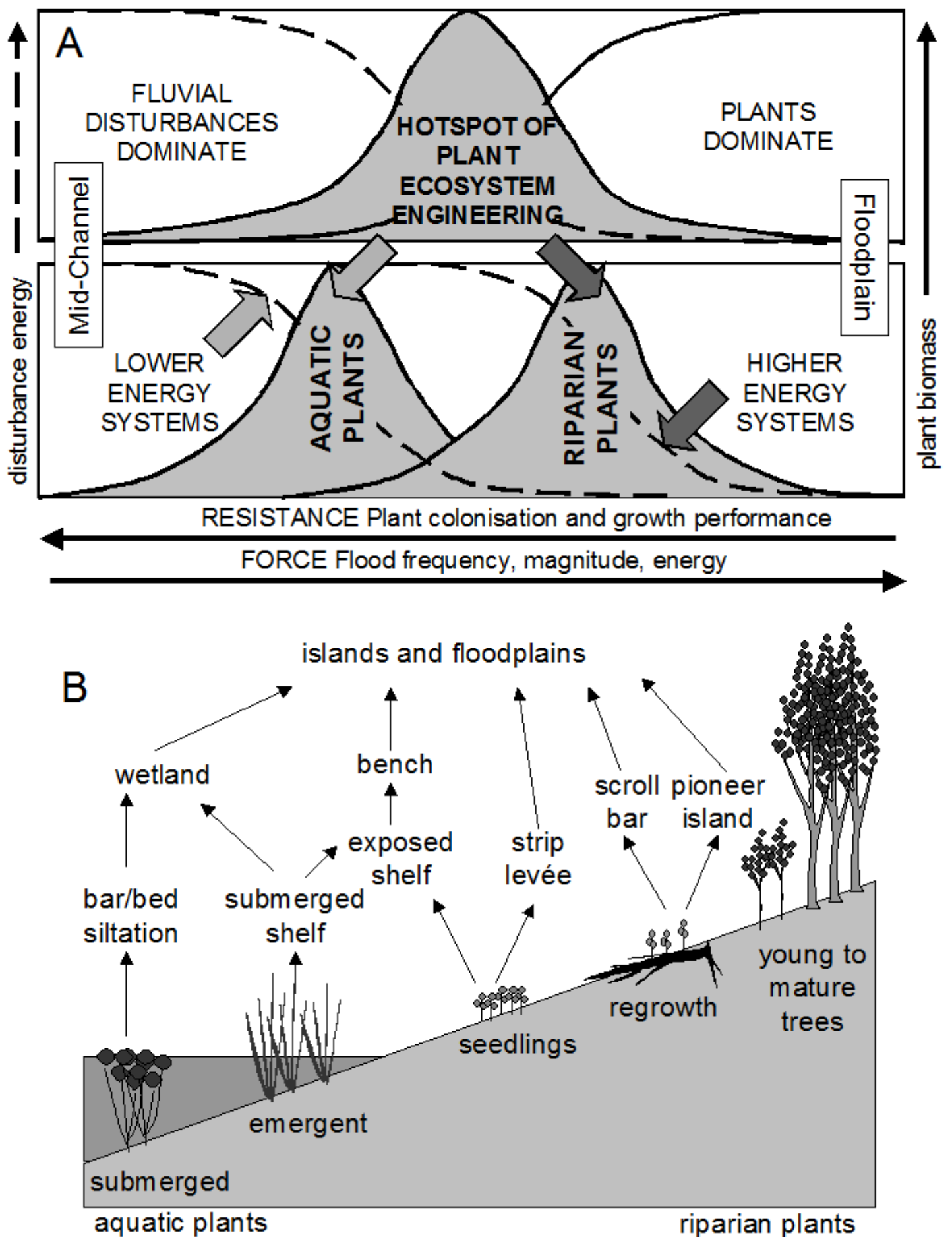

Figure 11

A. The location of hotspots of plant engineering between areas dominated by fluvial disturbances and by plants (upper graph) and the potential shift in hotspot location and plant engineer type between rivers of different energy.

B. Plant and propagule types that may act as ecosystem engineers, the pioneer landforms they may create and subsequent landform development trajectories towards island and floodplain development. 


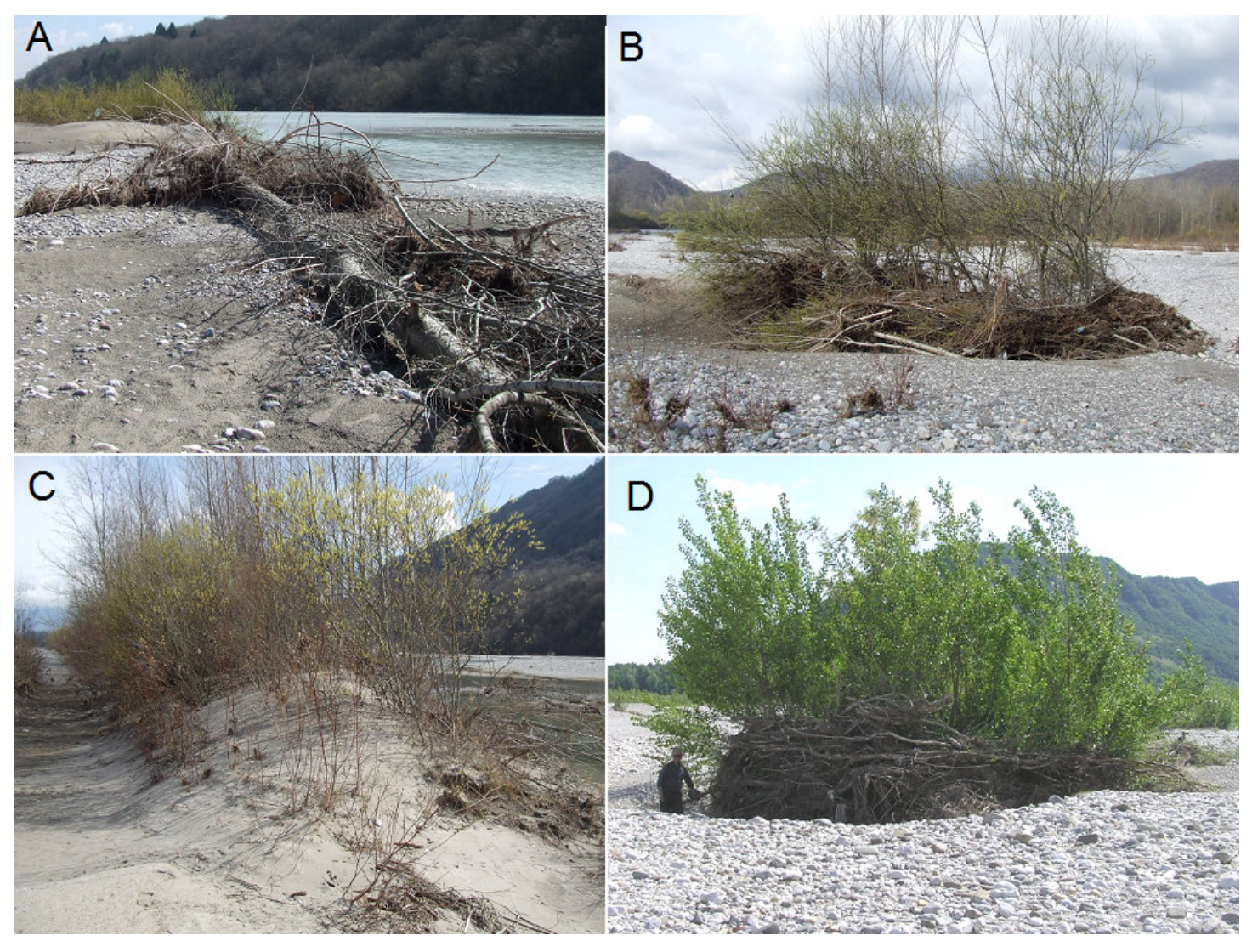

Figure 12. Island development on the Tagliamento River.
A. Uprooted,deposited tree (March);
B. Pioneer island, March;
C. Downstream end of a building island (March);
D. Pioneer island, May

(photographs by A. Gurnell) 


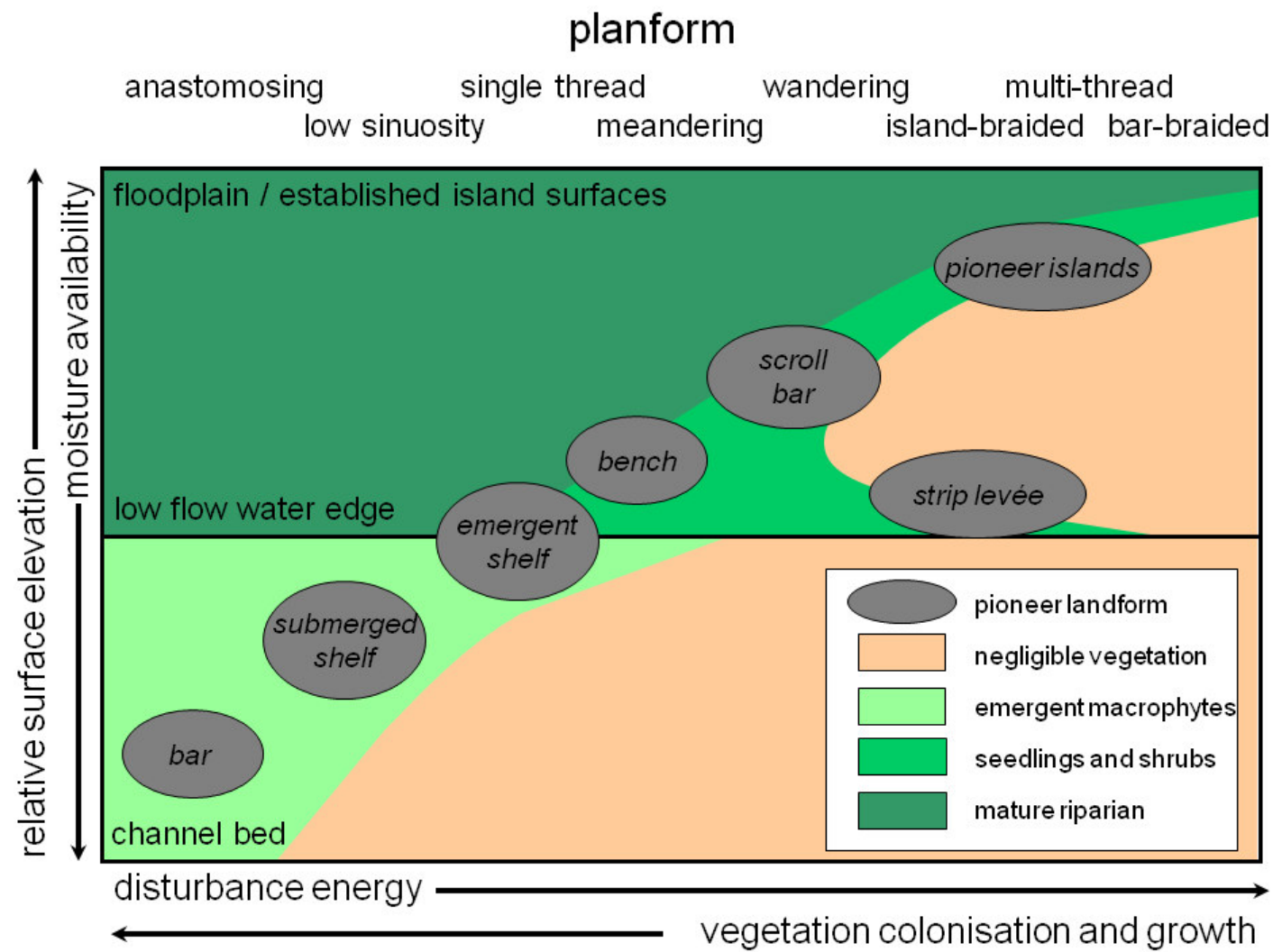

Figure 13 Schematic representation of the distribution of vegetation-associated pioneer landforms across rivers of different energy and planform. The landforms are located within hotspots of plant ecosystem engineering, which are located diagonally across the plot, occupying areas of increasing relative elevation within the cross profile of the river corridor as the frequency and energy of fluvial disturbances increases and/or the vigour of the vegetation decreases (modified after Gurnell et al., 2012). 